\title{
Advocacy in Non-Adversarial Family Law: A Recommendation for Revision to the Model Code
}

\section{Deanne M. Sowter*}

Family law is evolving towards non-adversarial dispute resolution processes. As a result, some family lawyers are representing clients who are trying to reach settlements that recognize their interests, instead of just pursuing their legal rights. By responding to the full spectrum of client needs, lawyers are required to behave differently than they do when they are representing a client in a traditional civil litigation file. They consider the emotional and financial consequences of relationship breakdown - things that are not typically within the purview of the family law lawyer. They objectively reality check with their clients, and they approach interest-based negotiations in a client-centric way. These lawyers view their role as that of a non-adversarial advocate, and their clients as whole people with interests that are not just legal. This paper draws on an empirical study involving focus groups with family law lawyers, to argue that the Federation of Law Societies of Canada's Model Code of Professional Conduct needs to be updated to incorporate non-adversarial advocacy. The lawyers in the study viewed non-adversarial advocacy as being responsive to client needs, and in the interest of clients' children. This paper draws from the study to establish what constitutes non-adversarial advocacy and then it presents a proposal for revising Rule 5 (Advocacy) of the Model Code.

Le droit de la famille évolue pour comprendre des processus non contradictoires de règlement des différends. Par conséquent, certains avocats en droit de la famille représentent des clients qui tentent de conclure des règlements reconnaissant leurs intérêts, au lieu de simplement faire valoir leurs droits reconnus par la loi. Pour répondre à l'ensemble des besoins des clients, les avocats sont tenus de se comporter différemment de la manière dont ils agissent lorsqu'ils représentent un client dans un dossier traditionnel de litige civil. Ils examinent les conséquences émotionnelles et financières de la rupture d'une relation, soit des éléments qui ne sont généralement pas du ressort des avocats en droit de la famille. Ils examinent objectivement la réalité avec leur client et abordent les négociations fondées sur les intérêts d'une manière axée sur le client. Ces avocats considèrent leur rôle comme celui d'un avocat non antagoniste, et leur client, comme une personne à part entière dont les intérêts ne sont pas seulement juridiques. L'article s'appuie sur une étude empirique menée auprès de groupes de discussion formés d'avocats spécialisés en droit de la famille pour soutenir que le Code type de déontologie

* Deanne Sowter is an Instructor at the University of Calgary, Faculty of Law, and a Research Fellow with the Winkler Institute for Dispute Resolution at Osgoode Hall Law School. A special thank you to the Ontario Bar Association Foundation for the 2015/16 Chief Justice of Ontario Fellowship in Legal Ethics and Professionalism Studies, which provided the funding for this project, and to Trevor Farrow, Nicole Aylwin and Martha Simmons of the Winkler Institute for Dispute Resolution for their helpful guidance and support. A warm thank you for the thoughtful comments provided by my anonymous peers, and to Amy Salyzyn, Lynn Mather and Alice Woolley for their comments on an earlier draft of this paper. Finally, a debt of gratitude to the twenty-eight participants for their honesty. 
professionnelle de la Fédération des ordres professionnels de juristes du Canada doit être mis à jour afin d'y intégrer la représentation en justice non contradictoire. Les avocats ayant participé à l'étude considèrent que la représentation non contradictoire répond aux besoins des clients et est dans l'intérêt des enfants de ces derniers. L'article s'inspire de l'étude pour établir ce que constitue la représentation en justice non contradictoire, puis présente une proposition de modification de la règle 5 (Représentation en justice) du Code type.

Contemporary family law practice requires that the family lawyer's philosophical map be redrawn so that she sees herself first and foremost as a conflict manager and problem solver. ${ }^{1}$

-Action Committee on Access to Justice in Civil and Family Matters (The "Cromwell Report")

\section{INTRODUCTION}

The practice of family law is evolving towards non-adversarial alternative dispute resolution [ADR] ${ }^{2}$ processes. As a result, some family lawyers are representing clients who are trying to reach settlements that recognize their interests, instead of just pursuing their legal rights. By responding to the full spectrum of client needs, lawyers are required to behave differently than they do when they are representing a client in a traditional civil litigation file. They are considering the emotional and financial consequences of relationship breakdown - things that are not typically within the purview of the family law lawyer. These lawyers view their role as that of a non-adversarial advocate, and their clients as whole people with interests that are not just legal. The question is, does the Model Code need to be updated to reflect this shift in practice? This paper argues that it does.

The standard conception of the lawyer's role is to enable and protect "a client's participation in the legal system" and to facilitate "a client's ability to make decisions about what to do in relation to what the law permits, proscribes or enables." 3 Or, framed another way, the lawyer's role is to pursue her client's interests within the bounds of legality. ${ }^{4}$ Generally speaking, the norms governing appropriate lawyer behaviour are established by law societies (rules and disciplinary decisions), legislation, and case law. ${ }^{5}$

1 Action Committee on Access to Justice in Civil and Family Matters, "Final Report of the Family Justice Working Group: Meaningful Change for Family Justice: Beyond Wise Words” (April 2013) online: Canadian Forum on Civil Justice $<$ https://www.cfcj-

fcjc.org/sites/default/files/docs/2013/Report\%20of\%20the\%20Family\%20Law\%20WG\%20Meaningful\%20Change $\% 20$ April\%202013.pdf $>$ at 30 [Cromwell Report].

2 For the purpose of this paper, ADR includes negotiation, mediation, and collaborative practice. In some instances, ADR can also refer to arbitration, however, that process is still adversarial in nature.

3 Alice Woolley, "Lawyer as Fiduciary: Defining Private Law Duties in Public Law Relations" (2015) 65:2 UTLJ 285 at 288 [Woolley, "Fiduciary"].

4 David Tanovich, "Law's Ambition and the Reconstruction of Role Morality in Canada" (2005) 28 Dalhousie LJ 267.

5 Alice Woolley, "Introduction to Legal Ethics" in Alice Woolley et al, eds, Lawyers' Ethics and Professional Regulation, 3rd ed (Toronto: LexisNexis Canada, 2017) at 8 [Woolley et al, Lawyers' Ethics]. 
However, appropriate lawyer behaviour is also dictated by the dispute resolution process, ${ }^{6}$ and local practice norms. ${ }^{7}$ For example, the norms of collaborative practice $[\mathrm{CP}]$ require a lawyer to be a legal problem-solver who works with opposing counsel to reach a consensus. ${ }^{8}$ ADR's unique behavioural norms are also developed through communities of practice, ${ }^{9}$ creating fundamental challenges for the role of the lawyer. How can a client know what to expect of her lawyer when there are no substantive or procedural rules, nor judicial oversight? How ought regulators to govern lawyers when they are operating in processes where the rules of engagement are defined by the practice community? A non-adversarial advocate must listen, advise and problem-solve, in order to pursue the best deal she can for her client, which may include recognition of interests that are only relevant in an interest-based process. ${ }^{10}$

This paper draws on a study involving focus groups with family law lawyers (the "Toronto Study") ${ }^{11}$. The Toronto Study sought to define practice norms by looking at what lawyers perceive as unethical behaviour in family law ADR. ${ }^{12}$ The participants believe that resolving conflict through a non-adversarial process is beneficial for the client, and is in the interest of her children. They view non-adversarial advocacy as being responsive to client needs. Two important themes regarding advocacy emerged from the study: (1) a family lawyer ought to objectively reality-check with her client; and, (2) she ought to approach interest-based negotiation in a client-centric way. These two themes are not currently reflected in the Model Code. ${ }^{13}$

This paper draws from the Toronto Study to propose revision to the Model Code for non-adversarial advocacy. It begins with a discussion about the uniqueness of family law, and how ADR is responding to its challenges. Part III draws from the Toronto Study to establish what constitutes non-adversarial

6 Deanne Sowter, "Professionalism \& Ethics in Family Law: The Other 90\%" (2016) 6.1 J Arbitration \& Mediation 167 [Sowter, "Professionalism"].

7 Lynn Mather, Craig A. McEwen and Richard Maiman, Divorce Lawyers at Work: varieties of professionalism in practice (Oxford: Oxford University Press, 2001); Woolley et al, Lawyers' Ethics, supra note 5 at 8.

8 See generally Julie Macfarlane, "The Emerging Phenomenon of Collaborative Family Law (CFL): A Qualitative Study of CFL Cases" (Family, Children and Youth Section, Department of Justice, Canada, 2005) [Macfarlane, "Emerging Phenomenon"]; Martha Simmons, "Collaborative Law at 25: A Canadian Study of a Global Phenomenon" (2016) 49:2 UBC Law Review 669 [Simmons, "Collaborative Law"].

9 Carrie Menkel-Meadow, "Ethics and Professionalism in Non-Adversarial Lawyering" (1999) 27 Fla St U L Rev 153 at 162 [Menkel-Meadow, "Non-Adversarial"]; Deanne Sowter, Winkler Institute for Dispute Resolution, "Overview Report - Professionalism \& Ethics in Family Law: The Other 90\%" (May 2017); Carrie Menkel-Meadow, "The Evolving Complexity of Dispute Resolution Ethics" (2017) 30 Geo J Legal Ethics 389 at 405 [Menkel-Meadow, "Evolving Complexity"]; Julie Macfarlane, "The New Lawyer: How Clients are Transforming the Practice of Law" (Vancouver: UBC Press, 2017) [Macfarlane, "New Lawyer"]; Mather, supra note 7 at 113; Sowter, "Professionalism, supra note 6.

10 See generally Roger Fisher \& William Ury, Getting to Yes (Toronto: Penguin Books, 2011).

11 Sowter, "Professionalism," supra note 6.

12 Ibid.

13 Federation of Law Societies of Canada, Model Code of Professional Conduct (14 March 2017)

[Model Code]. The only Law Society to introduce guidance unique to family law is the Law Society of British Columbia; Law Society of British Columbia, "Report of the Family Law Task Force: Best Practice Guidelines for Lawyers Practicing Family Law" (15 July 2011), online: LSBC

$<$ https://www.lawsociety.bc.ca/Website/media/Shared/docs/publications/reports/FamilyLaw-guidelines_2011.pdf $>$ [LSBC, "Report"]; Law Society of British Columbia, "Common Sense Guidelines for Family Law Lawyers" (1 May 2013), online: <LSBC https://www.lawsociety.bc.ca/support-and-resources-for-lawyers/discipline-advisories/may-1,2013/> [LSBC, "Guidelines"]. 
advocacy. Part IV presents a proposal for revising Rule 5 (Advocacy) of the Model Code. Revision would bring the Model Code up to date by reflecting the movement towards ADR in family law and provide for non-adversarial lawyering generally.

\section{FAMILY LAW}

Between 1991 and 2011, approximately five million Canadians separated or divorced. ${ }^{14}$ In 2016/17, there were 291,742 active family law cases, affecting 583,484 people, not including their children. Of those cases, 41,388 had been active for more than four years. ${ }^{15}$ Recent research shows that in any three year period, 1,216,497 Canadians will experience a family law problem, including problems caused by relationship breakdown, and child related matters. ${ }^{16}$ ADR processes are used in the majority of family law files - at the very least, negotiation. Studies from 2010/11 show that only $1 \%$ of divorce cases reached the trial stage, ${ }^{17}$ and $80 \%$ of divorces were uncontested. ${ }^{18}$ These statistics do not include couples who separate but never divorce, or were never married. ${ }^{19}$ These statistics show the weight family law places on the justice system, and the impact it has on Canadians.

However, Canada has an access to justice problem. ${ }^{20}$ The complexity of issues faced by family law clients, and the inability of the justice system to meet those needs is central to the discussion. ${ }^{21}$ Family

14 Statistics Canada, Social and Aboriginal Statistics Division, "Parenting and Child Support After Separation or Divorce," by Marie Sinha, Catalogue No 89-652-X (Ottawa: Statistics Canada, February 2014) at 5.

15 Statistics Canada, "Active family cases by issue(s) identified over length of case and number of fiscal years since case initiation, Canada and selected provinces and territories," Table 35-10-0113-01 (Ottawa: Statistics Canada, 2018) (66,130 had been active for between 1-2 years; 22,928 were active for 2-3 years; and, 12,278 had been active for between 3-4 years).

16 Canadian Forum on Civil Justice, "Everyday Legal Problems and the Cost of Justice in Canada: Overview Report," by Trevor CW Farrow et al (Toronto, 2016), online: <http://www.cfcj-

fcjc.org/sites/default/files/Everyday\%20Legal\%20Problems\%20and\%20the\%20Cost\%20of\%20Justice\%20in\%20Canad a\%20-\%20Overview\%20Report.pdf> at 7; Noel Semple, "A Third Revolution in Family Law Dispute Resolution: Accessible Legal Professionalism" (2017) 34:1 Windsor YB Access Just 130 at 132 [Semple, "Third Revolution”].

17 Statistics Canada, Juristat, "Divorce Cases in Civil Court, 2010/11" by Mary Bess Kelly, catalogue no. 85-002-X (Ottawa: Statistics Canada, March 2012) at 5, 13 (Based on six reporting provinces and territories; excludes Ontario because Ontario includes trials for uncontested divorces which renders the figures incomparable.).

$18 \mathrm{Ibid}$, at 5 (There were 113,000 divorces in the seven reporting provinces and territories in $2010 / 11$, which is $35 \%$ of all family law cases.).

19 Statistics Canada, "2016 Census of Canada: Data tables, Marital Status (13), Age (16) and Sex (3) for the Population 15 Years and Over of Canada and Forward Sortation Areas," Catalogue No 98-400-X2016039 (Ottawa: Statistics Canada, 13 September 2017) (13,383,455 married spouses and 3,510,260 common law couples).

20 Hryniak v Mauldin, [2014] 1 SCR 87 (SCC) at para 1 [Hryniak]; Canadian Forum on Civil Justice, supra note 16 at 1112,16 (Canadians spend approximately $\$ 6,100$ on legal problems, which is almost as much as Canadian households spent on average on food in 2012, and almost three times as much as they spent on out-of-pocket health care expenses $(\$ 2,285) ; 51 \%$ of the respondents surveyed claimed to suffer stress or had emotional difficulty as a direct consequence of having a legal problem; the cost to the state as a result of social assistance, loss of employment, mental and physical health issues, caused by experiencing a legal problem is approximately $\$ 800$ million per year.).

21 Julie Macfarlane, "The National Self-Represented Litigants Project: Identifying and Meeting the Needs of SelfRepresented Litigants - Final Report" (May 2013), online: <https://representingyourselfcanada.com/wpcontent/uploads/2016/09/srlreportfinal.pdf >; Allison Jones, "Canada's 'adversarial' family law system targeted" CTV News (16 March 2011); Tonda Maccharles, "Troubled family court system needs urgent overhaul, report says," The Star 
law matters are complex, involving emotional and financial issues. They involve vulnerable third parties, namely children. Various reports have been commissioned to conceptualize solutions to the problem, which often focus on non-adversarial processes. ${ }^{22}$ In 2013, the Cromwell Report emphasized the importance of non-adversarial advocacy. They found that the traditional role of the "zealous advocate is too restricted for the unique and diverse demands of" family law practice, and concluded that family lawyers require "expertise not only in substantive family law, litigation procedures, and traditional advocacy, but equally, in the theory and practice of CDR and conflict resolution advocacy."23

Reform initiatives emphasize ADR and non-adversarial lawyering. ${ }^{24}$ The unique implications of process on family law were first recognized in the 1970s when mediation developed, and by 1986 the Divorce Act was amended to require lawyers to advise their clients about mediation. ${ }^{25}$ In 2018, the Federal government introduced Bill C-78 to amend the Divorce Act again, this time to expand the scope of dispute resolution processes to include other out of court options such as CP. ${ }^{26}$ In British Columbia, the new Family Law Act came into force in 2013. ${ }^{27}$ It was drafted to be reflective of new policy objectives including: structuring the "law so that court is not the only implied starting point;" the promotion of a "broader range of non-court dispute resolution options;" and the "use [of] less adversarial terminology."28 In Ontario, reform efforts focus on "front-end loading" the system to divert families away from litigation. ${ }^{29}$

(29 March 2013); Christie Blatchford, "Getting to the Root of Ontario's Family Law Mess," National Post (21 March 2017); Sean Fine, "Ottawa appoints four new judges as pressure mounts to help clogged courts," The Globe and Mail (12 April 2017); Erin Anderssen, "Why Canada needs a split from its messy divorce laws," The Globe and Mail (15 December 2017); Semple, "Third Revolution," supra note 16.

22 John McCamus et al, "Report of the Ontario Legal Aid Review: A Blueprint for Publicly Funded Legal Services" (1997) Commissioned Reports, Studies and Public Policy Documents, Paper 67; Law Society of Upper Canada, "Task Force on Paralegal Regulation Report to Convocation" (2004); Law Society of Upper Canada, "Paralegal Standing Committee Report to Convocation - November 22, 2012 (2007); Michael Trebilcock, Ministry of the Attorney General, "Report of the Legal Aid Review 2008" (2008); Action Committee on Access to Justice in Civil and Family Matters, "Access to Civil and Family Justice: A Roadmap for Change" (2013) [Roadmap]; Law Commission of Ontario, "Increasing Access to Family Justice Through Comprehensive Entry Points and Inclusivity" (Toronto, February 2013) [LCO, "Increasing Access"]; Chris Bentley et al, Ryerson University Legal Innovation Zone, "Legal Innovation Zone's Family Reform Community Collaboration" (February 2016); Manitoba Family Law Reform Committee, "Modernizing Our Family Law System" (2018) [Manitoba FLRC]; Cromwell Report, supra note 1.

23 Cromwell Report, ibid at 30.

Bill C-78, An Act to Amend the Divorce Act, the Family Orders and Agreements Enforcement Assistance Act and the Garnishment, Attachment and Pension Diversion Act and to make consequential amendments to another Act, 1st Sess, 42nd Parl, 2018 (as passed by the House of Commons February 6, 2019) [Bill C-78]; Cromwell Report supra note 1; Manitoba FLRC, supra note 22.

25 Divorce Act, RSC 1985 c 3 (2nd Supp) at s 9(2).

26 Bill C-78, supra note 24 at cl 1(7).

27 Family Law Act, SBC 2011 c 25 [BC Family Law Act].

28 British Columbia, Ministry of Attorney General Justice Services Branch Civil Policy and Legislation Office, "White Paper on Family Relations Act Reform" (July 2010) at i.

29 LCO, "Increasing Access," supra note 22 at 28-29. 
In Manitoba, non-adversarial dispute resolution processes are currently the focus of a three-year pilot project. $^{30}$

This paper does not propose that litigation has no place in resolving family law disputes, because it does. There are families who cannot or will not cooperate, who require a third party decision-maker to protect the rights of both parties. However, litigation is often ill suited for family law. A recent decision from Manitoba explains why:

\begin{abstract}
Report after report has stated that the adversarial system is ill suited for divorcing couples who are seeking to reframe their familial relationships in a fair and prompt manner. It is ill suited for essentially two reasons. First, conflicts between spouses are not comparable to disputes between strangers given that they entail much more than resolving legal differences. There are emotional, psychological and financial aspects that also need to be resolved. Second, unlike other types of disputes, marital disputes have an ongoing nature to them either because of spousal and/or child support issues or of continued parenting responsibilities. ${ }^{31}$
\end{abstract}

As will be discussed below, these two differences support the idea that ADR and non-adversarial lawyering are central to resolving family law disputes, requiring a lawyer to behave differently than she would in a civil litigation conflict.

\title{
A. Family Law is Different
}

Family law is a type of civil litigation. It involves the pursuit of rights and the defence of claims. The majority of family law legislation and jurisprudence is focused on the care of children, and the economic consequences of the dissolution of the family unit, legal rights that are designed for an adversarial system. $^{32}$ The uniqueness of family law has been acknowledged by academics and policy-makers. ${ }^{33}$ Family law poses challenges to the traditional adversarial model of lawyering in the following ways: (1) the issues that are relevant (emotional, financial, and legal); (2) the ongoing nature of a family law file (reviews and variations ${ }^{34}$ ); and, (3) the impact of family violence. Each of these challenges will be discussed briefly, including how ADR is positioned to respond.

30 Deanne Sowter, “Can we reframe the family law reform conversation, please?” (4 November 2017), online (blog): Justice Innovation Blog < https://winklerinstitute.ca/can-we-reframe-the-family-law-reform-conversation-please/>; Manitoba FLRC, supra note 22.

31 Dunford v Birnboim, [2017] WDFL 5564, 284 ACWS (3d) 339 (MB CA) at para 5 [Dunford].

32 See for e.g. Divorce Act, supra note 25; Family Law Act, RSO 1990, c F3 [ON Family Law Act]; Children's Law Reform Act, RSO 1990 c C 12; Family Law Act, SA 2003 c F-4.5 [AB Family Law Act]; BC Family Law Act, supra note 27.

33 John-Paul Boyd, "The Need for a Code of Conduct for Family Law Disputes" (29 April 2016), online (blog): Slaw $<$ http://www.slaw.ca/2016/04/29/the-need-for-a-code-of-conduct-for-family-law-disputes/>; American Academy of Matrimonial Lawyers, "Bounds of Advocacy" (November 2000) [AAML, "Bounds of Advocacy"]; Nicholas Bala, Patricia Hebert \& Rachel Birnbaum, "Ethical Duties of Lawyers for Parents Regarding Children of Clients: Being a Child-Focused Family Lawyer” (2017) 95:3 The Canadian Bar Review 557; Dunford, supra note 31; Cromwell Report, supra note 1 at 14.

34 Divorce Act, supra note 25 at s 17. 


\section{Relevance of Emotional, Financial and Legal Issues}

Family law involves a unique intersection of emotional, financial and legal issues. It involves rights provided by the law - compensation for sacrifices made for the family unit, ${ }^{35}$ entitlement to benefit from the increase in net family wealth, ${ }^{36}$ and financial support for the ongoing care of children. ${ }^{37}$ It also deals with rights that are people-oriented, rather than act-oriented, such as custody and access. ${ }^{38}$ Second, family law requires the resolution of economic issues, which are often tied to emotional issues. For example, determining compensatory spousal support monetizes decisions the couple made as a family unit - the decision to be a stay-at-home parent may be financially compensated. ${ }^{39}$ In addition, the dissolution of the family unit requires people to plan for their financial future, including evaluating what kind of life they can afford to live now that they are living in two homes. ${ }^{40}$ Third, emotional information is relevant information that may be at the root of the relationship breakdown, about whether a spouse committed adultery, or lied about their sexual orientation. Emotional information is not legally relevant since the introduction of no-fault divorce, ${ }^{41}$ but it is relevant to a client making decisions in an interest-based process. ${ }^{42}$

Family law issues themselves are emotional and value laden, creating additional complexity for the role of the lawyer. ${ }^{43}$ LSUC $v$ Ludmer involved a lawyer who was accused of professional misconduct for aggressively over-identifying with his client to the point of incivility. ${ }^{44}$ Over-identification with clients may be problematic in many areas of law, but the personal nature of family law creates a challenge for separating the client's problems from the lawyer's personal history. ${ }^{45}$ Ludmer demonstrates that lawyers are not immune to the emotional challenges of family law. The LSUC (now Law Society of Ontario) Tribunal wrote the following:

35 See for e.g. AB Family Law Act, supra note 32 at ss 56-63; Divorce Act, ibid at s 15.2; ON Family Law Act, supra note 32 at Part III.

36 See for e.g. ON Family Law Act, ibid at Part I; Matrimonial Property Act, RSA 2000, c M-8; and the doctrine of unjust enrichment for cohabiting couples, see generally Kerr v Baranow, [2011] 1 SCR 269, 93 RFL ( $\left.6^{\text {th }}\right) 1$ (SCC).

37 See generally Divorce Act, supra note 25 at s 15.1; ON Family Law Act, supra note 32 at Part III; AB Family Law Act, supra note 32 at ss $47-55.8$.

38 Young $v$ Young, [1993] 4 SCR 3, WDFL 5593 (SCC) at para 78.

39 Moge v Moge, [1992] 3 SCR 813 (SCC) [Moge].

40 The ability to structure a spousal support settlement in a way that considers the financial future of both parties, see generally Rollie Thompson \& Carol Rogerson, Family, Children and Youth Section, Department of Justice, Canada, "Spousal Support Advisory Guidelines" (July 2008) [SSAG]; Rollie Thompson \& Carol Rogerson, Family, Children and Youth Section, Department of Justice, Canada, "Spousal Support Advisory Guidelines: The Revised User's Guide" (April 2016) [RUG].

41 Mary Jane Mossman et al., Families and the Law: Cases and Commentary, 2nd ed (Toronto: Captus Press, 2015) at 348 (No fault divorce was introduced in 1968 with the enactment of the Federal Divorce Act.).

42 Sowter, "Professionalism," supra note 6 at 205.

43 Gerald L Clore, "The Law as Emotion Regulation" (2009) 16 Va J Soc Pol'y \& L 334 at 336; Clare Huntington, "Repairing Family Law" (2008) 57 Duke LJ 101; Katharine B Silbaugh, "Money as Emotion in the Distribution of Wealth at Divorce" (2006) Boston Univ School of Law Working Paper No 07-05; Cromwell Report, supra note 1 at 14.

44 Law Society of Upper Canada v Ludmer, 2017 ONLSTH 28 (Law Society Tribunal - Hearing Div) [Ludmer].

45 Sowter, "Professionalism," supra note 6 at 201. 
[15] Family law involves personal and intimate matters and the most vulnerable members of our society - children. The issues can lead clients and lawyers to feel passionately, particularly when we have our own histories. However, clients will not be well served if lawyers cannot work together on effective and proportionate dispute resolution and solutions to the issues. We must separate clients' views from those of lawyers and recognize that, as lawyers, we only fully have one side of the story. What is more, clients will not be well served by personal incivility in contentious matters. After all, if lawyers are not civil to each other on a personal level, how can we expect spouses involved in a family breakup, the most stressful time of their lives, to do so? What are we modelling? The legal profession will fall in the public eye if lawyers act in an unprofessional and uncivil manner. ${ }^{46}$

ADR is positioned to respond to the wide range of client interests by not limiting disclosure to what is legally relevant; and, by providing a forum to recognize the range of interests involved. Being a nonadversarial advocate in a process designed to fulfill these functions allows a lawyer to respond to the full range of client interests, where appropriate.

\section{The Ongoing Nature of a Family Law File}

Most civil litigation disputes are linear: there is an incident, a claim, and a resolution, then the parties go their separate ways. In family law, the parties may remain connected if they have children; meaning, they will remain in each other's lives, at the very least attending family functions. If there are support obligations, they may be financially connected for an indefinite duration. ${ }^{47}$ Family law involves reviews and variations, meaning the parties may revisit issues when there is a change in circumstances. ${ }^{48}$ In other words, family law issues are not always linear and do not necessarily allow for a clean break. ${ }^{49}$ Clients may need to communicate over time. ${ }^{50}$ An adversarial approach is not conducive to the good will required to resolve future disputes. ${ }^{51} \mathrm{Few}$ other areas of civil litigation require preservation of the parties'

$46 \quad$ Ludmer, supra note 44 at para 15.

47 Divorce Act, supra note 25 at ss 2(1) and 15.1 (child support may be owed until the child completes his first degree, at least); SSAG, supra note 40; RUG, supra note 40 (spousal support may be ordered for an indefinite duration if the rule of 65 applies, the relationship was longer than 20 years, or the child support formula applies).

48 Divorce Act, ibid at s 17.

49 For a discussion of the "clean break" policy and the impact on the feminization of poverty, see generally Messier $v$ Delage, [1983] 2 SCR 401, 2 DLR (4 $\left.{ }^{\text {th }}\right) 1$ (SCC); Pelech Trilogy (Pelech v Pelech [1987] 1 SCR 801, 38 DLR (4 $\left.{ }^{\text {th }}\right) 641$ (SCC); Caron v Caron, [1987] 1 SCR 892, 38 DLR (4 $\left.{ }^{\text {th }}\right) 735$ (SCC); Richardson v Richardson, [1987] 1 SCR 857, 38 DLR $\left(4^{\text {th }}\right) 699$ (SCC)); Bracklow v Bracklow, [1999] 1 SCR 420, 169 DLR (4 $\left.{ }^{\text {th }}\right) 577$ (SCC); Moge, supra note 39.

50 Cromwell Report, supra note 1 at 15.

51 Joanne Paetsch, Lorne Bertrand and John-Paul Boyd, Canadian Research Institute for Law and the Family, Canadian Forum on Civil Justice, "An Evaluation of the Cost of Family Law Disputes: Measuring the Cost Implications of Various Dispute Resolution Methods" (December 2017), online: <http://www.cfcj-fcjc.org/sites/default/files/docs/CostImplication-of-Family-Law-Disputes.pdf $>$ at 34 (92.9\% of lawyers who practice collaboratively and $82.5 \%$ of lawyers who represent clients in mediation find that those two processes make it easier for parties to cooperate in the future; as compared to $18.5 \%$ and $6.4 \%$ for arbitration and litigation respectively.). 
relationship, and in contrast, often destroy the relationship - or are arm's length to begin with. ${ }^{52}$ By recognizing the interconnectivity of the family unit, particularly where there is a child, ADR and nonadversarial advocacy allow parties to preserve their relationship. ${ }^{53}$

\section{Family Violence}

The terms domestic violence [DV] and intimate partner violence [IPV] have varying definitions, generally related to whether there are legal protections available. ${ }^{54} \mathrm{DV}$ refers to physical abuse by an intimate partner towards his spouse and her children. ${ }^{55} \mathrm{IPV}$ generally includes physical, sexual, emotional, and financial violence, as well as other controlling behaviours such as stalking, by an intimate partner towards his spouse or partner. ${ }^{56}$ Family violence includes all of the above. ${ }^{57}$

The Ontario Domestic Violence Death Review Committee reviewed 289 cases from between 20032016, involving 410 deaths. Of the cases reviewed, approximately $73 \%$ involved a couple with a history of DV, and $67 \%$ of cases involved a couple with an actual or pending separation. ${ }^{58} \mathrm{~A}$ history of DV and an actual or pending separation are the top two risk factors of death at the hands of an intimate partner. ${ }^{59}$ In $2017,30 \%$ of police-reported violent crime involved victimization by an intimate partner. ${ }^{60}$ That year there were 96,000 cases of IPV reported, ${ }^{61}$ making it the leading type of violence experienced by women. ${ }^{62}$ Significantly, 7 in 10 victims indicated that the police had never been made aware of the violence, because they viewed abuse as a private matter. ${ }^{63}$ Approximately half of those who are separating report that they have been a victim of physical violence by their partner at least once during cohabitation, and $75 \%$ report

52 Arguably, some areas of employment law, estate litigation, and some civil disputes such as those with a neighbor may involve consideration of whether the parties will need / want to preserve their relationship.

53 Martha Simmons, "Increasing innovation in legal process: the contribution of Collaborative Law" (PhD, Osgoode Hall Law School, 2015) [unpublished] online:

$<$ https://yorkspace.library.yorku.ca/xmlui/bitstream/handle/10315/30050/Simmons_Martha_E_2015_PhD.pdf?sequence $=2 \&$ isAllowed $=y>$ at 23 [Simmons, "Increasing Innovation"].

54 Margaret B Drew, "Collaborative and Coercion: Domestic Violence Meets Collaborative Law" (2012) 1 Irish L J1 27 at 33 [Drew, "Coercion"].

55 Ontario, Office of the Chief Coroner "Domestic Violence Death Review Committee: 2016 Annual Report" (September 2017) at 3 [Ontario, "Domestic Violence"].

56 World Health Organization, "Understanding and Addressing Violence Against Women" (2012) at 1; see also Statistics Canada, Juristat, "Family Violence in Canada: A Statistical Profile, 2016," by Marta Burczycka \& Shana Conroy, Catalogue No 85-002-X (17 January 2018) at 56 (IPV sometimes only refers to violent Criminal Code offences against victims aged 15 and older within an intimate relationship.) [Statistics Canada, "Family Violence 2016"]; Statistics Canada, Juristat, "Family Violence in Canada: A Statistical Profile, 2017," by Marta Burczycka, Shana Conroy \& Laura Savage, Catalogue No 85-002-X (5 December 2018) at 22 [Statistics Canada, "Family Violence 2017"].

57 Protection Against Family Violence Act, RSA 2000 c P-27 at 1(e); Bill C-78, supra note 24 at cl 1(7); Drew, "Coercion," supra note 54 at 32-33.

58 Ontario, "Domestic Violence," supra note 55 at 1 and 14 (65\% of the cases were homicides, and 35\% were homicidesuicides).

$59 \quad$ Ibid at 14.

60 Statistics Canada, "Family Violence 2017," supra note 56 at 22.

61 Ibid

62 Ibid.

63 Statistics Canada, "Family Violence 2016," supra note 56 at 56. 
being a victim of emotional abuse. ${ }^{64}$ Given the number of people affected by some form of family violence, it is likely that a family lawyer will represent a client who is either a victim or abuser.

There are unique advocacy challenges when safety is the paramount concern, and the client is vulnerable. ${ }^{65}$ The litigation system is adversarial in nature, allowing a controlling spouse to use litigation tactics involving emotional, financial and physical abuse. ${ }^{66}$ Research shows that rage against family courts, which the abuser perceives as depriving him of his children, home, money and masculinity, is a motivating factor for men who admit to physically assaulting their spouse. ${ }^{67}$ Adversarial proceedings "escalate the level of conflict to a point where estranged partners use court proceedings and court-ordered arrangements to harass and abuse each other." ${ }^{68}$ In contrast, research shows that DV rarely occurs during and following CP and mediation. ${ }^{69}$ That said, handling DV cases in non-adversarial processes is not without controversy, particularly mandatory mediation programs. ${ }^{70}$ There is criticism that the lack of judicial oversight may exacerbate power dynamics between the spouses and revictimize the wife (emotionally, and with respect to her capacity to consent to a settlement) and so it may leave her with less than the law would provide. ${ }^{71}$ However, literature also shows that a victim knows her own safety best, and if she consents to a non-adversarial process she may willingly accept less than the law would provide in exchange for safely leaving the relationship. ${ }^{72}$ Non-adversarial lawyering in an ADR process can prioritize safety by: (1) emphasizing safety planning and screening - accredited collaborative practitioners, ${ }^{73}$

64 Desmond Ellis, "Divorce and the Family Court: What Can be Done About Domestic Violence?" (2008) 46 Fam Ct Rev 531 at 531 .

65 The complexity caused by family violence is beyond the scope of this paper, see generally Nancy Ver Steegh, "Yes, No, and Maybe: Informed Decision Making About Divorce Mediation in the Presence of Domestic Violence" (2003) 9 Wm \& Mary J Women \& Law 145; Noel Semple, "Mandatory Family Mediation and the Settlement Mission: A Feminist Critique" (2012) 24:1 CJWL 207 [Semple, "Mandatory Mediation"]; Margaret B Drew, "Collaboration and Intention: Making the Collaborative Family Law Process Safe(r)” (2017) 32 Ohio St. J on Disp Resol 373 [Drew, "Safe(r)”]; Cromwell Report, supra note 1 at 16; Drew, "Coercion," supra note 54.

66 See for e.g. Linda Neilson, Family Children and Youth, Department of Justice, "Enhancing Safety: When Domestic Violence Cases are in Multiple Legal Systems (Criminal, family, child protection) A Family Law, Domestic Violence Perspective," $2^{\text {nd }}$ ed (Ottawa: Department of Justice, 2013) (the fragmentation of the court system is a leading cause of the failure to protect women and children); Laura Kane, "BC girls' death prompts debate about how judges handle domestic-violence cases," The Globe and Mail (7 January 2018); Ellis, supra note 64.

67 Ibid at 531-532.

68 Ibid at 531.

69 Ibid at 532.

70 Wanda Wiegers, Jennifer Koshan, \& Janet Mosher, "Domestic Violence and Alternative Dispute Resolution in Family Law Disputes" (15 November 2018), online (blog): ABlawg < https://ablawg.ca/2018/11/15/domestic-violence-andalternative-dispute-resolution-in-family-law-disputes/>.

71 Semple, "Mandatory Mediation," supra note 65.

72 Drew, "Safe(r)," supra note 65; Drew, "Coercion," supra note 54; see also Lauren Pelley, "Leaving Relationship is 'most dangerous time' for domestic violence victims, experts say," CBC News (8 December 2016).

73 Ontario Collaborative Law Federation, "The OCLF Advanced Collaborative Professional Designation" (5 March 2019), online: oclf.ca $<$ https://oclf.ca/resources/the-oclf-advanced-collaborative-professional-designation/> (requires 21 hours of DV training to qualify for accreditation) [OCLF, “Accreditation"]. 
mediators ${ }^{74}$, and arbitrators ${ }^{75}$ are required to have some form of family violence training, whereas lawyers are not: ${ }^{76}$ (2) not being conducive to tactics that perpetuate a continuation of the abuse; and, (3) not antagonizing the abuser by increasing the conflict.

\section{B. ADR is Responding}

Family law has five process options: negotiation, mediation, ${ }^{77}$ arbitration, ${ }^{78} \mathrm{CP},{ }^{79}$ and litigation. They can be used simultaneously, with the exception of $\mathrm{CP}$, or contracted in tandem, such as mediation-

74 Family Law Act Regulation, BC Reg 347/2012 at s 4 [BC FLA Reg]; Wainwright $v$ Wainwright, [2012] WDFL 3323, 21 RFL $\left(7^{\text {th }}\right) 415$ (ON Sup Ct J); Hilary Linton, “Understanding Each Party's Power in Family Mediation-Arbitration: Why it is critical" (July 2014), online: Mediate.com <https://www.mediate.com/articles/LintonH2.cfm>.

75 Arbitration Act, 1991, SO $1991 \mathrm{c} 17$ at ss 58(d) and (e); Family Arbitration, O Reg 134/07; BC FLA Reg, ibid at s 5.

76 BC FLA Reg, ibid at ss 4-6; BC FLA, supra note 28 at s 8(1)(a) (implies that a lawyer is required to screen in order to assess whether family violence may be present, the extent to which it may adversely affect the safety of the party or family member, and the party's ability to negotiate a fair agreement); Law Commission of Ontario, "Curriculum Modules in Ontario Law Schools: A Framework for Teaching About Violence Against Women" (August 2012); Olivia Carville, "Law schools fail on domestic violence training, experts say" The Toronto Star (3 February 2015).

77 Mavis Maclean \& John Eekelaar, Lawyers and Mediators: The Brave New World of Services for Separating Families (Portland, OR: Hart Publishing, 2016) at 123 ("Evaluative mediation seeks to reach a settlement in accordance with the rights of the parties within the anticipated range of court outcomes, which can blur the line between mediation and arbitration"); Katie Shonk, "Types of Mediation: Choose the Type Best Suited to Your Conflict" (3 December 2018), online (blog): Program on Negotiation, Harvard Law School $<$ https://www.pon.harvard.edu/daily/mediation/typesmediation-choose-type-best-suited-conflict/> (Facilitative mediation: "Rather than making recommendations or imposing a decision, the mediator encourages disputants to reach their own voluntary solution by exploring each other's deeper interests. [...] mediators tend to keep their own views regarding the conflict hidden." Evaluative mediation: the mediator is more likely to make a recommendation, suggestions, and express opinions; "[i]nstead of focusing primarily on the underlying interests of the parties involved, evaluative mediators may be more likely to help parties assess the legal merits of their arguments and make fairness determinations." Transformative mediation: empowers disputants to resolve their conflict and encourages them to recognize each other's needs and interests. "At its most ambitious, the process aims to transform the parties and their relationship through the process of acquiring the skills they need to make constructive change."); Martha Simmons, Mediation: A Comprehensive Guide to Effective Client Advocacy (Toronto: Emond, 2016) at 5-6 ("the focus of the mediation is most often on substantive rights held by the parties: who is right and who is wrong." They point out weakness of the case and make recommendations; it is a "process of shared understanding and creative option generation [...] the focus is on the relationship between the parties"). Arbitration Act, supra note 75 (includes parenting coordination).

$79 \mathrm{CP}$ is an interest-based ADR process that requires both lawyers to subscribe to the same values and philosophy of practice. The features of $\mathrm{CP}$ are: good faith negotiation, full disclosure, disqualification provision of the participation agreement ("PA"), and in some cases the interdisciplinary team. At the commencement of a collaborative file, both parties sign the PA, and both lawyers sign it as their lawyers, not parties. In Ontario, both lawyers must be members of the Law Society of Ontario, and be collaboratively trained. The PA sets out the rules of the negotiation. For e.g., the Ontario Collaborative Law Federation [OCLF] PA provides that the parties need to deal with each other in good faith; and they need to make timely, full, candid and informal disclosure, and update information that has materially changed. Disclosure includes financial and emotional information because they are relevant to the parties' interests. The enforcement mechanism in $\mathrm{CP}$ is the disqualification provision. Collaborative lawyers are required to withdraw if the client is behaving uncollaboratively. For e.g., if the client is withholding or misrepresenting important information, the lawyer must withdraw; or, if the client refuses to honour agreements, delays without reason, or otherwise acts contrary to the principles of CP. This provision upholds the integrity of good faith negotiations. It is beyond the scope of this paper, but this provision is in contrast to how a lawyer's role is typically viewed, particularly as it relates to the lawyer's duty of 
arbitration. Or, a couple may try negotiation and only commence mediation or litigation if the negotiation stalls or fails. Others may pursue litigation first, and attempt to settle the case through the use of "litigotiation." ${ }^{80}$ Litigotiation uses the litigation process to strategically pursue a settlement - combining the adversarial nature of litigation with a parallel non-adversarial negotiation. The choice and timing of the process used is a complicated decision, influenced by a range of factors such as: timelines, costeffectiveness, selection of the neutral, privacy, the need to maintain ongoing relationships, and the personalities involved. ${ }^{81}$

An interest in non-adversarial processes may be due to family law burnout, ${ }^{82}$ the desire to alleviate the impact of separation on children, ${ }^{83}$ or a response to the issues raised above. A recent study by the Canadian Research Institute for Law and the Family found that family lawyers prefer CP and mediation for resolving disputes (with the exception of high conflict cases), because they are better able to meet the interests of their clients and their children, ${ }^{84}$ and they are faster and more cost effective ${ }^{85}$ The same study found CP

loyalty. No other dispute resolution process includes a mechanism which functionally matches a lawyer's moral compass instead of the client's. In CP, if a client wants to delay without reason, it is the lawyer who decides whether the reason is valid, not the client. The disqualification provision states that the parties will not resort to litigation, and if they do, the lawyers must not act in the litigation or any other non-consensual adversarial process. As a result, the disqualification provision serves as an incentive for both parties to settle, and for both counsel to cooperate with each other. The parties have also agreed not to use the threat to withdraw from CP as a means of forcing a settlement. The interdisciplinary team model is also a unique feature of CP. In Ontario, CP operates with two lawyers, and potentially a jointly retained neutral financial professional and /or family professional. The OCLF provides a list of approved professional designations for the neutrals, and requires that they be in good standing of a recognized professional regulatory body, and collaboratively trained. In other jurisdictions a team may include divorce coach(es) and/or a child specialist. Ontario Collaborative Law Federation, "Participation Agreement" (2018) at paras 2.1(a), 2.2(a), 3.2, 5.2, 5.3, and 10.1 [unpublished]; Michaela Keet, Wanda Anne Wiegers \& Melanie Morrison, "Client Engagement Inside Collaborative Law" (2008) 24:2 Can JFam L 145; Wanda Anne Wiegers \& Michaela Keet, "Collaborative Family Law and Gender Inequalities: Balancing Risks and Opportunities" (2008) 46 Osgoode Hall LJ 733; Sowter, "Professionalism," supra note 6 at 194; Macfarlane, "Emerging Phenomenon," supra note 8; Macfarlane "New Lawyer," supra note 9; Simmons, "Increasing Innovation," supra note 53.

80 Marc Galanter, “A Settlement Judge, not a Trial Judge: Judicial Mediation in the United States” (1985) 12 J L \& Soc'y 1.

81 Lorne Wolfson, Settling Family Law Cases: Practical Techniques for Advocates and Neutrals, (Toronto: Thomson Reuters, 2017) at 31-33.

82 Martha Simmons, "Collaborative Law," supra note 8 at 671 (CP was first conceived of by Stu Webb in Minnesota, USA, in 1990, partly in response to what he saw as a rise of incivility amongst family lawyers. He wanted to create a process in which he could serve the best interests of his client, while also avoiding what he called "family law burnout".).

83 Bala, Hebert \& Birnbaum, supra note 33; see also Bill C-78, supra note 24.

84 Paetsch, Bertrand \& Boyd, supra note 51 at 30-32 (94\% of collaborative lawyers and 90.2\% of lawyers representing their clients in mediation strongly agree or agree that results they achieve through those processes are in their client's interests, as compared to $34.2 \%$ and $31.2 \%$ of lawyers who arbitrate and litigate respectively. Similarly, $98.9 \%$ of collaborative lawyers and $85.4 \%$ of lawyers who represent their clients in mediation agreed or strongly agreed that the results they achieve through those processes are in the interest of their client's children, as compared to $39.5 \%$ and $30.2 \%$ of arbitrators and litigators respectively. $91.7 \%$ of collaborative lawyers, and $79.6 \%$ of lawyers representing clients in mediation prefer to resolve disputes through those processes as compared to arbitration or litigation; whereas $74.3 \%$ of lawyers who litigate disagree or strongly disagree that litigation is their preferred choice.)

85 Ibid at 30 (Collaborative and mediation are more cost effective in resolving disputes than litigation and arbitration: In collaborative and mediation, typical low-conflict disputes take 5.0 and 4.8 months to resolve respectively, whereas arbitration and litigation take 6.6 and 10.8 months; for high conflict disputes those durations are: 14.8 (collaborative), 
and mediation are better suited to creating long lasting resolutions, ${ }^{86}$ which is critical for the ongoing nature of family law issues. Reform initiatives are incorporating non-adversarial processes for family law. ${ }^{87}$ Despite these trends, there is little guidance for expected lawyer behaviour in a non-adversarial ADR process, and sometimes no procedural or substantive rules. ${ }^{88}$ The Toronto Study sought to begin to fill that gap.

\section{III - THE TORONTO STUDY}

\section{A. Methodology}

The research relied on focus groups as the primary method of gathering personal and reflective data about lawyers' understanding of what constitutes ethical behaviour in negotiation, $\mathrm{CP}$, and mediation. Focus groups were chosen as the research method because they are ideal for gathering data about community norms, and observing group interaction. ${ }^{89}$ Focus groups provide an opportunity for participants to "spark off one another" to explore dimensions individuals may not have considered. ${ }^{90}$ The data from the focus groups was organized into themes and compared and contrasted.

The focus groups took place between February and April of 2016. There were six discussions, two devoted exclusively to each process: mediation, CP, and negotiation. During each discussion, the participants were told to frame their discussions within the process. In other words, the participants in the negotiation focus groups only talked about negotiation, concurrent to litigation, and where no application had been commenced. The collaborative practitioners spoke only of conduct within $\mathrm{CP}$, having signed a PA. ${ }^{91}$

There were twenty-eight participants in total; $68 \%$ were female and $32 \%$ were male. All of the participants were from the Greater Toronto Area. The participants had been practicing law for between nine and thirty-five years. Of the twenty-eight participants, $86 \%$ were collaboratively trained, ${ }^{92}$ and $68 \%$

13.7 (mediation), 14.8 (arbitration), and 27.7 (litigation). Total cost for typical low conflict disputes are: \$6,269 (collaborative), \$6,345 (mediation), \$12,328 (arbitration), \$12,395 (litigation). Total cost for typical high conflict disputes are: $\$ 25,110$ (collaborative), $\$ 31,140$ (mediation), $\$ 40,107$ (arbitration), $\$ 54,390$ (litigation).).

86 Ibid at 29 (Dispute resolution process which results in the most long lasting resolutions of family law disputes: $71.1 \%$ (collaborative), $78.3 \%$ (mediation), 16.9\% (arbitration), 22.3\% (litigation).).

87 Manitoba FLRC, supra note 22; Bill C-78, supra note 24.

88 See generally Robert A Baruch Bush, "A Study of Ethical Dilemmas and Policy Implications" (1994) 1 J Disp Resol 1; Michael Coyle, "Defending the Weak and Fighting Unfairness: Can Mediators Respond to the Challenge?" (1998) 36:4 Osgoode Hall LJ 625; Julie Macfarlane, "Mediating Ethically: The Limits of Codes of Conduct and the Potential of a Reflective Practice Model" (2002) 40:1 Osgoode Hall LJ 49; Trevor Farrow, "The Negotiator as Professional:

Understanding the Competing Interests of a Representative Negotiator" (2007) 7 Pepperdine Disp Resol LJ 373 [Farrow, "Negotiator"].

89 Monique M Hennink, Focus Group Discussions: Understanding Qualitative Research (New York: Oxford University Press, 2014) at 28.

90 Herbert Rubin \& Irene Rubin, Qualitative Interviewing: The Art of Hearing Data (Thousand Oakes: Sage Publications, 1995) at 140.

91 See footnote 79 for a description of a PA.

92 Collaborative training for membership in a local practice group typically consists of 5 days of training, see for e.g. Collaborative Practice Toronto, "Explore your Membership Options" (5 March 2019), online: collaborativepracticetoronto.com <https://collaborativepracticetoronto.com/for-professionals/>; OCLF, "Accreditation," 
were trained mediators. ${ }^{93}$ The participants were all selected through the researcher's personal contacts; first a pool of participants who were known to have the required training and scope of practice was created, and then the pool was randomly reduced to avoid bias in selection. ${ }^{94}$ All of the participants were guaranteed confidentiality and anonymity in accordance with York University's Office of Research Ethics protocol. ${ }^{95}$

There were on average five participants in each focus group and each focus group session was ninety minutes in length. The participants were told to consider the Rules of Professional Conduct, ${ }^{96}$ and their own moral compass when answering questions. They were given no additional guidance during the discussions in order to prevent them from being biased by the researcher. ${ }^{97}$ For a complete list of the discussion questions, see Appendix "A".

They were first asked to describe what constitutes unethical behaviour in the process that was the subject of that focus group. This paper does not present the full results, which have been published elsewhere. ${ }^{98}$ The following draws on the focus groups about $\mathrm{CP}$ and negotiation. The first section describes how the collaborative participants viewed advocacy, defining what they called settlement advocacy; followed by how the participants in the negotiation focus groups viewed their role. The subsequent two sections consider the main themes that flow from these observations: (a) a client-centered interest-based approach; and (b) reality checking.

\section{B. Collaborative Practice}

The collaborative lawyer participants described a uniform approach to advocacy which seemed to be based on a shared value system dictated by the process. They agreed that zealous advocacy, as described below, was unethical in CP and had been replaced with settlement advocacy. They defined settlement advocacy as follows:

- Varies in strength (facilitative to more traditional - without being adversarial) and it may vary in strength over the course of a file depending on the needs of the client;

- Interest-based - duty of the lawyer to listen to their client and their goals and interests;

- Considers more than the legal model (i.e. considers interests; financial consequences and feasibility);

- Encompasses consideration of third party interests (meaning the family unit);

supra note 73 (accreditation as a collaborative practitioner requires an additional 40 hours of training which includes 6 hours of advocacy in CP, and 21 hours DV training).

93 The collaborative lawyers had completed their initial collaborative training between the years 2000 and 2015, and the mediators had completed their initial training between the years 1992 and 2014. CP accreditation was introduced in 2018, so none of the participants had been accredited as collaborative practitioners at the time of the focus groups.

94 Richard A Krueger \& Mary Anne Casey, Focus Groups: A Practical Guide for Applied Research, 5th ed (Thousand Oakes, CA: Sage Publications, 2015) at 80.

95 York University Ethics Approval Certificate Number: 2016-037.

96 Law Society of Ontario, Rules of Professional Conduct (25 January 2018).

97 Uwe Flick, An Introduction to Qualitative Research, 4th ed (Thousand Oakes, CA: Sage Publications, 2009) at 199.

98 Sowter, "Professionalism," supra note 6. 
- Requires reality checking; ${ }^{99}$ and,

- Empowers the client to make informed decisions. ${ }^{100}$

When asked to describe zealous advocacy, one participant described it as: "game playing, really strategic, taking advantage, poking them when I can. ... Never seeking to understand." (CR2, P2) Another participant described it as: "withholding information, attacking the other person, strictly law, grinding them down, not caring about the other person's needs or interests." (CR2, P4) The difference between zealous advocacy and settlement advocacy was described as:

[Zealous advocacy is] the driving... It's the, I'm in charge of driving the bus to get you there and the casualties along the way don't matter. Whereas in settlement advocacy, there's an awareness of the impact ... Whereas zealous advocacy is, be damned with the impact, we're going for the throat ... we're defining success by a very narrow definition of success. Whereas in settlement advocacy, we're expanding with our clients because the client's definition of success is more about ... Can I co-parent? Did I spend an okay amount of money? Did this take an okay amount of time? ... Am I financially okay? Do I feel okay with the choices I made and the thing I signed? (CR2, P2)

Even though the Model Code does not require zealous advocacy but rather resolute advocacy, ${ }^{101}$ the collaborative participants described tension between their duty as a resolute advocate under the Rules, and their role as an advocate in $\mathrm{CP}$, suggesting there is a difference. For example, they viewed resolute advocacy as aggressive and focused on winning, whereas settlement advocates look for a resolution that will meet the needs of both clients, as opposed to a win. By not pursing a win however, are the lawyers failing to fulfill their duty as a resolute advocate, particularly given that family law is a type of civil dispute under Rule 5.1-1 ${ }^{102}$ One participant questioned whether it is really in the client's best interest to be a resolute advocate: "There is a question about whether or what does zealous advocacy mean and is that really in a client's best interest, right because it has gone to the utmost extreme, really. I think there is some discomfort in the general legal community about that term now and the implications of that." (CR2, P8) Another participant said that in general, "There is a lot conflict between the rules of practice and

99 Merriam-Webster Dictionary, (online: https://www.merriam-webster.com/dictionary/reality\%20check) at sub verbo "reality check" ("something that clarifies or serves as a reminder of reality often by correcting a misconception"); Dictionary.com, (online: https://www.dictionary.com/browse/reality-check) at sub verbo "reality check" ("a corrective confronting of reality, in order to counteract one's expectations, prejudices, or the like"); see also Colleen M. Hanycz, Trevor CW Farrow \& Frederick H Zemans, "The Theory and Practice of Representative Negotiation" (Toronto: Emond Montgomery Publications, 2008) at 74.

100 Sowter, "Professionalism," supra note 6 at 198-199.

101 Model Code, supra note 13 at R 5.1-1 [4] (Advocacy); see generally Tim Dare, "Mere-Zeal, Hyper-Zeal and the Ethical Obligations of Lawyers" (2004) 7:1 Leg Ethics 24; Alice Woolley, “Against a Lawyer's Duty to Be 'Zealous' or 'Resolute"' (15 March 2018), online (blog): Slaw <http://www.slaw.ca/2018/03/15/against-a-lawyers-duty-to-bezealous-or-resolute/>.

102 Model Code, ibid at R 5.1.1[1] (Ask every question). 
collaborative values and protocols." (CR1, P7) These concerns demonstrate that collaborative lawyers approach their role differently.

The collaborative participants consider the wellbeing of the family unit; unlike the Model Code, which only requires lawyers to encourage a client to take into account the best interest of the child, if it does not prejudice the legitimate interests of the client. ${ }^{103}$ The expanded duty was described as maintaining paramountcy for the client while considering the whole family. One participant said:

I really see it as... you're still putting your client first, it's just that you're opening your mind, that maybe what's in the best interest of the family is also what is in the best interest of your client. Instead of an older more traditional approach where you don't care so much about the impact on others in the family unit - you only care about the impact on your client, not realizing ... that the impact on the children and spouse, does have a huge impact on [the] client. (CR1, P6)

A few participants had concerns about a broader perceived duty given its subjectivity and the potential for a paternalistic interpretation of it, but they were in the minority.

The participants described "good" settlement advocates as:

- Letting go of personal judgment;

- Modeling good behaviour for their clients;

- Listening to their client's goals and interests;

- Teaching their client to communicate effectively with their spouse; and,

- Acknowledging their counterpart counsel is working just as hard with their own client. ${ }^{104}$

What is striking about the description of "good" advocacy is the subjective measure of success involved. For example, letting go of personal judgment requires a person to be self-reflective to recognize when she is being judgmental. Is good behaviour defined by a lawyer's subjective view of what is right or wrong? The collaborative practitioners had a shared view of their role as an advocate, and it seemed to incorporate, at least at some level, a measure of their own morality ${ }^{105}$ - not just what was ethical pursuant to the Rules.

103 Ibid at R 5.1-1[4] (Advocacy).

104 Sowter, "Professionalism," supra note 6 at 198-199.

105 The theoretical debate about the role of morality in legal ethics is beyond the scope of this paper, see generally Charles Curtis, "The Ethics of Advocacy" (1951) 4:3 Stanford Law Review 3; Monroe Freedman, "Professional Responsibility of the Criminal Defence Lawyer: The Three Hardest Questions" (1966) 64 Mich L Rev 1469; Richard Wasserstrom, "Lawyers as Professionals: Some Moral Issues" (1975) 5:1 Human Rights 1; Charles Fried, "The Lawyer as Friend: The Moral Foundations of the Lawyer-Client Relationship" (1976) 85: 8 Yale LJ 1060; William Simon, "Ethical Discretion in Lawyering" (1988) 101:6 Harv L R 1083; Katherine Kruse, "Beyond Cardboard Clients in Legal Ethics" (2010) 23 Geo J Leg Ethics 103; Alice Woolley \& Bradley Wendel, "Legal Ethics and Moral Character" (2010) 23:4 Geo J Leg Ethics 1065; Alice Woolley, "The Problem of Disagreement in Legal Ethics Theory" (2013) 26:1 Can JL \& Jur 181; Alice Woolley, "Context, Meaning and Morality in the Life of the Lawyer" (2014) 17:1 Leg Ethics 1. 


\section{Negotiation (with or without the commencement of a court application)}

The participants in the negotiation focus groups did not define advocacy. Some of them did incorporate a sense of their own morality (a subjective sense of what was right and wrong) in their views. They agreed that family law requires a "higher ethical standard," 106 given the impact on children, and society. They frequently referred to a guiding principle for lawyers of doing no harm. ${ }^{107}$ For example:

What we've talked about, and I think it was discussed at a higher level, in terms of what we think our role is, in terms of do no harm, and trying to help people to see the other side. Some lawyers go into it thinking their job, what they're paid to do, and what constitutes doing a good job, is being in there, and being aggressive, and no holds barred. ... Zealous advocacy, and with few limitations. (NR2, P16)

Where this guiding idea failed to unify them however, was in the context of client instructions. A lawyer is required to provide legal advice based on the information provided by his client and further investigation, and then follow his client's instructions. ${ }^{108} \mathrm{~A}$ lawyer may refuse to follow client instructions where they amount to abuse of process, are dishonourable or dishonest, or involve deceiving a court or mediator. ${ }^{109}$ Some participants agreed their only duties were to their clients and the administration of justice. ${ }^{110}$ They viewed their own discomfort with instructions as almost irrelevant. Whereas other participants seemed to struggle more with the conflict between client instructions and their own morality. Examples of instructions that were problematic included: instructions to delay proceedings (i.e. status quo is in their client's favour ${ }^{111}$ ); escalation of the conflict and increase of costs; and, threatening the other spouse through aggressive negotiation tactics, such as by threatening to force the sale of a beloved family cottage if the spouse does not comply with requests. ${ }^{112}$ One participant said:

[In response to an ethical dilemma] I'm having difficulties with this as well. ... [The behaviour] would offend my moral compass. The problem I also have is that, what if it is his instructions? Then I follow through with the instructions, and I'm a different person for my client. And I can tell him that you're being a jerk and an ass for doing this, but ... Would it be something I would withdraw over? Probably not. Would it be something I would do under protest? Yeah, I probably would. ... I would probably try to reframe it, but

106 Sowter, "Professionalism," supra note 6 at 183.

107 Ibid at 183 and 202.

108 Model Code, supra note 13 at R 3.2-1[3] and R 3.2-1[5](f) (Instructions), R 3.2-1[5](k) (Informed of settlement), R 5.11[7] (Advocacy - A lawyer must never waive a client's legal rights without the client's informed consent); Law Society of Alberta, Code of Conduct (April 26, 2018) at R 3.2-4 (Client Instructions: A lawyer must obtain instructions from the client on all matters not falling within the express or implied authority of the lawyer; the Model Code does not have a comparable rule) [LSA, Code].

109 Model Code, ibid at R 5.1-2 (When acting as an advocate, a lawyer must not), R 5.1-4 (Disclosure of Error or Omission), and R 3.2-7 (Dishonesty, Fraud by Clients or Others).

110 Ibid at R 5.1 (Advocacy) and R 5.6 (Encouraging Respect for the Administration of Justice).

111 See generally $M(A) v M(J)$, [2016] WDFL 5419, 270 ACWS (3d) 813 (ON CA); Spencer v Spencer, [1980] BCJ No 815, 20 RFL (2d) 91 (BC CA).

112 Sowter, "Professionalism," supra note 6 at 185-190. 
what if my client says, "Well this is what I want to do. I don't care if you think I'm a jerk or an ass, or if I am being a jerk and an ass, that's what I want to do." [Then I follow instructions.] (NR1, P18) $)^{113}$

Another participant said: "I don't believe that as lawyers we have to do whatever our clients instruct us. There are other demands of the practice, other clients, other things outside the practice ..." (NR1, P17) One participant said it was unethical to follow client instructions when the other spouse was emotionally or financially vulnerable, and the actions would take advantage of that vulnerability. Some participants said they would transfer the file if their advice to the client was ignored and the client's instructions made the lawyer feel uncomfortable proceeding. ${ }^{114}$ One participant said: "They're driving off a cliff, so to speak. I'm not going to be part of it. I'm not going for the ride." (NR2, P16) Another participant said he would tell his client: "I'm just not that kind of lawyer." (NR1, P14) When the participants were asked to define "that kind of lawyer," some participants described it as poor lawyering. For instance, one participant said: "Some lawyers... they don't counsel their clients. They view themselves as, "You're the boss, and you want $A, B, C, D$. I'm just going to go marching for it full on." (NR2, P15) ${ }^{115}$ So, assuming the instructions are not in breach of the Rules, that bad lawyer would follow them without discussing their wisdom with the client, but that is poor lawyering. Some participants questioned whether bad lawyers are just misguided. There are two themes that can be drawn from these observations that relate to advocacy. The first is the client-centric view the participants had overall, and the second is the requirement to reality check.

\section{Client-centric Interest-based Negotiation}

Interest-based negotiation seeks to focus on the parties' interests rather than their positions, and to invent options for mutual gain using objective criteria. ${ }^{116} \mathrm{CP}$ is interest-based negotiation. ${ }^{117}$ Negotiation in a non-CP file may be rights-based or interest-based, depending on the lawyers. The participants in the Toronto Study did not convey a uniform approach to negotiation, but they consistently viewed their clients as people with more than legal interests. The concept of being client-centric refers to the view that lawyers take of their clients as individuals with legal issues that are intertwined with other concerns, such as "relationships, loyalties, hopes, uncertainties, fears, doubts and values."118 This is opposed to the view that clients have purely legal rights and interests, irrespective of any additional concerns, what Katherine Kruse calls the problem of "legal objectification." "As discussed above, family law is naturally clientcentric, in that clients' interests are a complex mix of emotional, financial and legal issues. A client-centric view was a consistent theme in all of the focus groups. This view fits naturally with the goal in interestbased negotiation, of inventing options for mutual gain.

\footnotetext{
Ibid at 188 .

Model Code, supra note 13 at R 3.7-2 (Optional withdrawal).

Sowter, "Professionalism," supra note 6 at 205.

6 Fisher \& Ury, supra note 10 at 17.

MacFarlane, "Emerging Phenomenon," supra note 8 at 31.

8 Kruse, supra note 105 at 103.
}

119 Ibid. 
The collaborative participants explained that their goal is not to "win" but rather to serve their client's interests. ${ }^{120}$ At the commencement of the process, they ask the client what their goals and concerns are, and they focus on client interests throughout the negotiation. One of the participants framed it as follows: "I think the big piece is traditionally, it really is very legally focused. How do I get the best legal deal for my client? There really isn't an awareness of the things that are non-legal, that are interest, that are emotional, that are relational - a strictly zealous advocate." (CR2, P4) For example, clients may want to preserve a parenting relationship or ensure that both parties are financially secure. Meeting those goals requires lawyers to consider both parties' interests. Some participants discussed the need to have an ongoing conversation with the client about the importance of considering the interests and concerns of both parties: "I would say to my clients, 'to meet your interest you have to meet some of your spouse's there."' (CR2, P8) Another participant said:

It's about recognizing that you have a tension, a little bit, between advocating for your client's interest and needs and goals, in a process that requires you to find a 'yes-able'. You know, how the other person can say yes to [it]. It's about being astute to help a client realize it's in your interest that I understand what the other person wants. [I am] acting on your behalf in the best way I can by getting to know your spouse, to know what matters to them, what [are] their priorities so we can begin to negotiate and make trades for what's most important to each of you. ... A big piece of it is to ... know what support a client needs to be effective and make their best choices and to design your advocacy [in a way to] support what the client needs. That's the skill of it. That's the art of it. (CR2, P4)

A hallmark of $\mathrm{CP}$ is creative problem solving to meet both parties' interests, ${ }^{121}$ and it was reflected in their approach.

The participants in the negotiation focus groups talked about remembering that clients are people, often with vulnerable children. ${ }^{122}$ They did not go as far as the collaborative practitioners to consider the whole family, but they did emphasize the children's interests. For example, one participant said Rule 5.1-1[4] ${ }^{123}$ does not go far enough in terms of requiring lawyers to consider the impact of conflict on children.

It's not strong enough at all. At all. In my view, that's a serious problem that needs serious working ... You ought to be taking into account the children's best interests ... If you're actually, as a lawyer, doing something that you actually think to yourself is detrimental to the children's best interest, I actually think you ought not to do it. (NR2, P13)

A consistent theme was the desire to be mindful of the vulnerable state of the parties. One participant framed it as contributing to the solution, rather than the problem. ${ }^{124}$ They talked about the need to sit down

120 Sowter, "Professionalism," supra note 6 at 220.

121 MacFarlane, "Emerging Phenomenon," supra note 8 at xii and xiv.

122 Sowter, "Professionalism," supra note 6 at 184.

123 Model Code, supra note 13 at R 5.1-1[4] (Advocacy).

124 Sowter, "Professionalism," supra note 6 at 187. 
with the other side, and have a conversation rather than commence litigation. ${ }^{125}$ In that sense, they emphasized the benefits of a non-adversarial process. For example, one participant talked about how the tone of the file changes as soon as litigation is commenced: "The letters that you get prior to litigation being commenced are always quite pleasant. Then once the litigation's been commenced, your client is the worst possible lout, no good person." (NR2, P1) Another participant spoke about the need to try a non-adversarial process first, before resorting to litigation:

Just like in war, there's two ways of dealing with a conflict between nations. It's actually a three-fold way: you can not do anything; you can use diplomacy, which is really a form of negotiation; you can use [a] course that will lead to the act of war. The war here, in our civil society, where [there is] the rule of law, is litigation. ... Our best goal would always be, in family law cases, to have a consensual resolution. If you can't get that, you next best is, you have [to] get an order from a third party that actually has the power... You should always be trying to go to the most peaceful method. (NR2, P13)

While the Model Code $e^{126}$ and the Divorce $A c t^{127}$ both require counsel to encourage settlement, what it striking about these observations is the emphasis on minimizing conflict for the well-being of the client and her children. Dispute resolution theorists focus on the root of the conflict to identify the interests, and then resolve the conflict by transforming it into an opportunity for problem-solving. ${ }^{128}$ Recommendations for family law reform often require that lawyers reduce the conflict. ${ }^{129}$ One of the guiding principles of the Cromwell Report is that the family justice system should minimize conflict and its negative impact on children. ${ }^{130}$ The Law Society of British Columbia's Best Practice Guidelines for Lawyers Practicing Family Law, recommends that lawyers ought to "conduct themselves in a manner that is constructive, respectful and seeks to minimize conflict and should encourage their clients to do likewise." ${ }^{31}$ While the idea of minimizing conflict is objectively reasonable, in practice it may be problematic. It suggests that lawyers would need to decline to act where they perceive client instructions to be conflictual in nature. That said, some of the participants in the negotiation focus groups said it was unethical to escalate the conflict. ${ }^{132}$ There seems to be a consensus that good family lawyering involves objective common sense provided by counsel, particularly in light of the stakes involved for families and society; a theme that is also apparent in the participants' views on reality checking.

125 Ibid at 189.

126 Model Code, supra note 13 at R 3.2-4 (Encouraging compromise or settlement) and R 3.1-1(c)(v) (Competence).

127 Divorce Act, supra note 25 at s 9(2).

128 John Kleefeld et al, Dispute Resolution Readings and Case Studies (Toronto: Emond, 2016) at 27 and 55 (through enhanced communication, trust-building, and integrative problem solving).

129 LSBC, "Report," supra note 13 at 4; LSBC, "Guidelines," supra note 13 at 1; Cromwell Report, supra note 1 at 3.

130 Cromwell Report, ibid at 3.

131 LSBC, "Report," supra note 13 at 4.

132 Sowter, "Professionalism," supra note 6 at 187. 


\section{Reality Checking}

A consistent theme for both groups was the idea that advocacy requires a lawyer to advocate with her own client, not just against the other side. In a negotiation, the lawyer has "two negotiations occurring simultaneously: One with their bargaining opposite and one with their own client."133 Reality checking means two things: (1) negotiating with the client to manage their expectations and help them get the best deal they can; and, (2) objectively discussing the pros and cons of decisions with the client, including those provided at a time of emotional distress due to relationship breakdown. Reality checking means reframing instructions in a positive way, reminding the client that the dispute is not "zero sum". ${ }^{134}$ The participants agreed that reality checking is necessary to good family law lawyering. ${ }^{135}$ One collaborative lawyer said:

I think reality checking is huge. The hallmark of this is that I know my counterpart counsel is working. There is more advocacy with your own client, to get them to the table, to get them ready, to get them realistic, to get them to know the wisdom of hearing the other person ... That's more work, we used to have all that effort attacking the other side. ... I know all good counterpart counsel are working their butt off like I am, and ... That to me is advocacy, that's a huge piece of that. It is critical. (CR2, P4) ${ }^{136}$

One participant in a negotiation focus group said:

It's telling your clients when they're being unreasonable. ... It's being able to tell your own client, "You are being unreasonable. This is going too far. I think, for you, your strategy is better served by being in this range, or whatever it is." ... That sort of thing. ... Being able to tell your clients when they're being unreasonable is a key, key feature to this puzzle that is lost. (NR2, P19)

Another participant in the same discussion said:

They have to understand what it will look like if they don't settle. If they are simply holding on for emotional reasons, or they think an offer's going to get better, and you know it's not, because you've been beating down everything, etc... Then they should be nudged along and shown that it's a good result and it's the right thing to do, etc. ... Reality checking. (NR2, P33)

133 CB Wiggins \& LR Lowry, eds, Negotiation and Settlement Advocacy: A Book of Readings, 2nd ed. (St. Paul, MN: Thomson 2005) at 498; see also Farrow, "Negotiator," supra note 88.

134 Carrie Menkel-Meadow, "Toward Another View of Legal Negotiations: The Structure of Problem Solving” (1984) 31 UCLA L Rev 754 at 794.

135 Sowter, "Professionalism," supra note 6 at 203.

136 Ibid at 204. 
The concept of reality checking challenges our normative understanding of the role of the lawyer. ${ }^{137}$ The lawyer's role is not traditionally understood to include advocating with her own client. Advice, yes; advocacy, no. A lawyer must be loyal to her client. ${ }^{138}$ Her role is to provide her client with legal information and honest advice, take instructions, and pursue her client's interests competently. ${ }^{139}$ The Model Code provides that a lawyer needs to be honest and candid with her client, and the lawyer may be firm, if necessary, when she has concerns about the client's position. ${ }^{140}$ The Code assumes however that those discussions focus on legal interests, not the emotional, psychological and financial interests that are relevant in family law. Ultimately, if the client wants to make a morally foolish or damaging decision, that is her choice. ${ }^{141}$ The lawyer must approach representation with the understanding that the client is the moral agent, not the lawyer. ${ }^{142}$

Reality checking raises some concerns for files involving DV. Research about handling cases involving family violence in ADR shows that a victim knows her own safety best. The victim may need to relinquish legal entitlements that a court would uphold in order to preserve her safety. ${ }^{143}$ Does the lawyer advise her client (the abuser) not to pay more if she knows the client's spouse is vulnerable and will settle for less? Does the lawyer who is representing the abuser need to reality check in a way that includes consideration of how the abuser may respond towards the victim?

Despite the concerns and the obvious implication that family violence training ought to be mandatory for all family law lawyers, the concept of reality checking was consistently viewed as objectively good for families. Reality checking is reflective of the lawyer's role in negotiating an agreement, and the challenges for a client to make clear-headed decisions at a time of emotional upheaval. What is also striking about this objective is the concern the participants had that by being better lawyers, they are not adhering to their obligations under the Rules. ${ }^{144}$

137 Tanovich, supra note 4.

138 Model Code, supra note 13 at R 3.4 (Conflicts); Woolley, "Fiduciary," supra note 3.

139 Model Code, ibid at R 3.1-2 (Competence), R 3.2-2 (Honesty and Candour), and R 5.1 (Advocacy).

140 Ibid at R 3.2-2 (Honesty and Candour) and R 3.2-2[3] (Firmness with a client).

141 Alice Woolley, Understanding Lawyers' Ethics in Canada, 2nd ed (Toronto: LexisNexis, 2016) at 92 [Woolley, Understanding].

142 Ibid at 92.

143 Drew, "Coercion," supra note 54 at 43.

144 In addition to reality checking, two examples of Rules that could be broken by CP, yet are objectively for the benefit of the client(s) are: (1) asking a counterpart not to disclose something to their client so that the team can create a safe process when DV is involved, or so the team can determine how to proceed when the information is emotionally challenging, such as situations involving addiction or sexual orientation. It is a breach of a lawyer's fiduciary obligations not to divulge information to their client, and in breach of Model Code R 3.2-1[3] (making fully informed decisions); (2) a conflict of interest between preserving working relationships with other professionals and duty to the client, yet by having good working relationships with counsel it is thought to improve the process, Model Code R 3.4-1 (Conflicts of Interest), Sowter, "Professionalism," supra note 6 at 195 and 206. 


\section{PROPOSED REVISION TO RULE 5}

\section{A. Ethics in ADR}

There is an academic debate about lawyers' ethics in negotiation. ${ }^{145}$ The Model Code applies to lawyer conduct in every area of law, and every process. The debate, which is largely American, focuses on the types of behaviours that are not captured by the various ethical codes, behaviours that are arguable in terms of whether they are ethical. For example, one argument suggests that the lack of rules in ADR is acceptable or even encouraged, because it allows a lawyer to negotiate the best deal she can for her client without constraints on her ethical obligations - she can bluff and exaggerate in pursuit of the best deal. ${ }^{146}$ The American Bar Association has introduced "Ethical Guidelines for Settlement Negotiations," 147 but no comparable guidelines exist in Canada. However, the Law Society of Alberta Code of Conduct does provide that a lawyer may not lie to another lawyer during a negotiation. ${ }^{148}$ There was also an American academic debate about the ethics of CP. ${ }^{149}$ The debate subsided after the majority of State Ethics Opinions

145 Gerald Wetlaufer, "The Ethics of Lying in Negotiations" (1990) 76 Iowa L Rev 1218; Robert H Mnookin, "Why Negotiations Fail: An Exploration of Barriers to the Resolution of Conflict" (1993) 8:2 Ohio St J Disp Resol 235; Carrie Menkel-Meadow, "Ethics in Alternative Dispute Resolution: New Issues, No Answers from the Adversary Conception of Lawyers Responsibilities" (1997) 38 S Tex L Rev 407; Carrie Menkel-Meadow, "Ethics in ADR: The Many 'Cs' of Professional Responsibility and Dispute Resolution” (2001) 28 Fordham Urb LJ 979 [Menkel-Meadow, "Many C's”]; Andrea Kupfer Schneider, "Shattering Negotiation Myths: Empirical Evidence on the Effectiveness of Negotiation Style" (2002) 7 Harv Negot L Rev 143; Carrie Menkel-Meadow \& Michael Wheeler eds, What's Fair: Ethics for Negotiators (San Francisco: Jossey-Bass, 2004); Marjorie L Benson, “A Negotiating Ethics Study” (2005) 84 Can Bar Rev 593; Alex J Hurder, "The Lawyer's Dilemma: To Be or Not to Be a Problem-Solving Negotiator" (2007) 14 Clinical L Rev 253; George Tsakalis, "Negotiation Ethics: Proposals for Reform to the Law Society of Upper Canada's Rules of Professional Conduct” (2015) 5:4 UWO J Leg Stud 3; Farrow, "Negotiator,” supra note 88; Menkel-Meadow, "Evolving Complexity," supra note 9; Menkel-Meadow, "Non-Adversarial," supra note 9.

146 Hanycz et al, supra note 99 at 128.

147 American Bar Association, Section of Litigation, "Ethical Guidelines for Settlement Negotiations" (12 April 2002), online: American Bar Association $<$ https://www.americanbar.org/content/dam/aba/migrated/2011_build/dispute_resolution/settlementnegotiations.authchec kdam.pdf $>$.

148 LSA, Code, supra note 108 at R 7.2-2[1] (Lying) (The Law Society of Alberta is the only law society in Canada to regulate lying in a negotiation; however, it is unclear as to what lying means in the context of negotiation. For e.g., whether it includes lying about a bottom line, or not.) See also James J. White, "Machiavelli and the Bar: Ethical Limitations on Lying in Negotiation" (1980) Am B Found Res J 926; ABA Formal Opinion 06-439 "Lawyers' Obligation of Truthfulness," online: American Bar Association $<$ http://apps.americanbar.org/labor/lel-abaannual/papers/2006/42.pdf $>$.

149 Sandra S Beckwith \& Sherri Goren Slovin, "The Collaborative Lawyer as Advocate: A Response" (2002-2003) 18 Ohio St J Disp Resol 497; Christopher M Fairman, "Ethics and Collaborative Lawyering: Why Put Old Hats on New Heads?" (2002-2003) 18 Ohio St J Disp Resol 505; John Lande, "Possibilities for Collaborative Law: Ethics and Practice of Lawyer Disqualification and Process Control in a New Model of Lawyering” (2003) 64 Ohio St LJ 1315; Christopher M Fairman, "A Proposed Model Rule for Collaborative Law” (2005-2006) 21 Ohio St J Disp Resol 73; John Lande, "Principles for Policymaking about Collaborative Law and Other ADR Processes" (2007) 22 Ohio St J. Disp Resol 619; Christopher M Fairman, "Why we still need a model rule for collaborative law: A reply to Professor Lande" (2006-2007) 22 Ohio St J on Disp Resol 707; Christopher M Fairman, "Growing Pains: Collaborative Law and the Challenge of Legal Ethics” (2007) Ohio State University Moritz College of Law - Public Law and Legal Theory Working Paper 
found that the process is ethical, ${ }^{150}$ and the subsequent introduction of the Uniform Collaborative Law Act. ${ }^{151}$ The International Academy of Collaborative Professionals, which is predominantly an American organization, has also introduced Standards and Ethics [IACP Standards] to provide minimum ethical standards for collaborative practitioners. ${ }^{152}$ Their advocacy provision highlights the client's selfdetermination "recognizing that ultimately the clients are responsible for making decisions that resolve their issues" $" 153$ as opposed to third-party decision-makers. The IACP Standards also require the lawyer to "avoid contributing to interpersonal conflict of the clients, including when identifying and discussing the clients' interests, issues and concerns." ${ }^{154}$ A debate about the ethics of CP was anticipated in Canada, but it did not occur. ${ }^{155}$ In 2005, Julie Macfarlane conducted a study on CP, raising concerns about whether the practice was ethical. ${ }^{156}$ There has been little response. No Canadian jurisdiction has regulated $\mathrm{CP}$, though there is reference to CP in the British Columbia Family Law Act, ${ }^{157}$ and the proposed amendments to the Divorce Act. ${ }^{158}$

Series No. 109; J Herbie DiFonzo, "A Vision for Collaborative Practice: The Final Report of the Hofstra Collaborative Law Conference" (2010) 20 Hofstra L Rev 101.

150 Twelve states issued ethics opinions addressing CP, and all except one in 2007 from Colorado approved the use of CP, with appropriate precautions. See for e.g. Washington State Bar Association, "Informal Opinion: 2170" (2007), online: Global Collaborative Law Council <http://globalcollaborativelaw.com/wpcontent/uploads/2017/07/Ethics_Opinion_WA_Opinion_-2170.pdf>; Advisory Committee of the Supreme Court of Missouri, "Formal Opinion: 124" (20 August 2008), online: Missouri Courts

$<$ https://www.courts.mo.gov/file.jsp?id=11695>; South Carolina Bar, "Ethics Advisory Opinion 10-01" (2010), online: South Carolina Bar <https://www.scbar.org/lawyers/legal-resources-info/ethics-advisory-opinions/eao/ethics-advisoryopinion-10-01/>; Colorado Bar Association, "Ethics Opinion 115" (24 February 2007) online: Colorado Bar Association $<$ https://www.cobar.org/Portals/COBAR/Repository/ethicsOpinions/FormalEthicsOpinion_115.pdf?ver=2016-10-04104226-273>.

151 Uniform Collaborative Law Act, (2009) (US Legislation) (enacted in sixteen states).

152 International Academy of Collaborative Professionals, "Standards and Ethics" (March 2018), online: collaborativepractice.com $<$ https://www.collaborativepractice.com/sites/default/files/IACP\%20Standards\%20and\%20Ethics\%202018.pdf $>$ [IACP, Standards].

153 Ibid at 3.2(A).

154 Ibid at 3.2(E).

155 Bradley R Hunter, “Collaborative Law, Ethics and the Duty to Negotiate: The Canadian Experience,” (5 March 2019), online: American Bar Association $<$ https://www.americanbar.org/content/dam/aba/events/dispute_resolution/3_hunter_the_canadian_experience.pdf $>$; Macfarlane "Emerging Phenomenon," supra note 8 at 44.

156 Macfarlane, ibid at 49; Simmons, "Increasing Innovation," supra note 53 at 692 (issue of informed consent and whether clients can truly understand the impact it has on the lawyer's role; risk of coerced settlement due to the heightened financial consequences which would result if the parties had to retain new counsel and commence litigation; and, a party can withdraw from $\mathrm{CP}$ and commence litigation which would terminate the lawyer-client relationship for their spouse).

157 BC Family Law Act, supra note 27.

158 Divorce Act, supra note 25 at s 9(2); Bill C-78, supra note 24. 


\section{B. Proposed Rule 5}

The Model Code ought to be updated to recognize non-adversarial advocacy. The Model Code's rule of advocacy focuses on the lawyer's role in an adversarial proceeding. ${ }^{159}$ The rule states that, "as an advocate, a lawyer must represent the client resolutely and honourably within the limits of the law, while treating the tribunal with candour, fairness, courtesy and respect." ${ }^{60}$ In "adversarial proceedings," a lawyer must fearlessly raise "every issue, advance every argument and ask every question, however distasteful, that the lawyer thinks will help the client's case and to endeavor to obtain for the client the benefit of every remedy and defence authorized by law." 161 The rule emphasizes how a case should be presented to a third-party decision-maker to ensure a just outcome, ${ }^{162}$ and the responsibility to "ensure the proper functioning of the justice system." 163 There is no mention of non-adversarial processes under advocacy in the Code.

The Code provides that a competent lawyer is one that is skilled in $\mathrm{ADR}^{164}$ and encourages settlement. ${ }^{165}$ So the Code supports ADR, but it fails to reflect the corresponding change in the lawyer's role as an advocate in a non-adversarial process. The role of the lawyer in a negotiation ${ }^{166}$ is fundamentally different than in an adversarial proceeding. There is a different objective than what is possible in an adversarial process where the outcome is decided by a neutral third-party decision-maker. In a nonadversarial process, the parties' aim is to achieve consensus. Carrie Menkel-Meadow has suggested that a lawyer needs to reorient her role towards sharing responsibility to find a solution, viewing the other side not as an adversary, but rather as a joint-venturer or partner, and that ethical codes ought to reflect that shift. ${ }^{167}$

Non-adversarial advocacy is another way of saying "conflict resolution advocate,"168 "problemsolver"169 or "peace-maker." 170 Julie Macfarlane argued that another form of advocacy for family lawyers

159 Model Code, supra note 13 at R 5.1-1 (Advocacy).

160 Ibid at R 5.1-1 (Advocacy), R 1.1-1 (a tribunal is defined to include mediation).

161 Ibid at R 5.1-1[1] (Advocacy).

162 Ibid at R 5.1-2 (When acting as an advocate, a lawyer must not: (e) knowingly attempt to deceive a tribunal, or influence the course of justice by offering false evidence, misstating facts or law, presenting or relying upon a false or deceptive affidavit, suppressing what ought to be disclosed; (f) knowingly misstate the contents of a document, testimony of a witness, the substance of an argument, or the law; $(\mathrm{g})$ knowingly assert as true a fact when it's truth cannot be reasonably supported by the evidence or as a matter of which notice may be taken by the tribunal; (h) make suggestions to a witness recklessly or knowing them to be false; (i) deliberately refrain from informing a tribunal of any binding authority that the lawyer considers to be directly on point and that has not been mentioned by another party; (j) improperly dissuade a witness from giving evidence; (k) knowingly permit a witness or party to be presented in a false or misleading way; (l) knowingly misrepresent the client's position in the litigation or the issues to be determined in the litigation.).

163 Woolley et al, Lawyers' Ethics, supra note 5 at 391.

164 Model Code, supra note 13 at R 3.1-1(c)(vi) (Competence in ADR).

165 Ibid at R 3.2-4 (Encourage compromise or settlement).

166 Negotiation is at the heart of every ADR process, including mediation and collaborative practice.

167 Menkel-Meadow, "Non-Adversarial," supra note 9 at 162; Menkel-Meadow, "Evolving Complexity," supra note 9 at 405.

168 Macfarlane, "New Lawyer," supra note 9 at 115.

169 Menkel-Meadow, "Evolving Complexity," supra note 9 at 390; AAML, "Bounds of Advocacy," supra note 33.

170 Victoria Smith \& Deborah Graham, "The Spectrum of Advocacy in Collaborative Practice" (2011); Hanycz et al, supra note 99 at 275; Menkel-Meadow, "Non-Adversarial," supra note 9 at 162. 
has developed in response to lawyers working in non-adversarial processes where a different skill-set is required to be a competent lawyer. ${ }^{171}$ Carrie Menkel-Meadow argued that the problem solver or peacemaker is a forward-thinking model, allowing a lawyer to plan for the future and consider preventative strategies, not just past acts, defences and claims. ${ }^{172}$ The Cromwell Report suggested that family lawyers ought to be skilled in both resolute advocacy and conflict resolution advocacy - suggesting an advocacy spectrum. ${ }^{173}$ The American Bounds of Advocacy document requires "effective advocacy", which considers the client's best interests, including the "well being of children, family peace, and economic stability." 174

Settlement advocacy has been criticized for its inability to protect settlement victims, and its potential to produce bad private justice. ${ }^{175}$ The argument is that non-adversarial processes may create settlement victims, parties who are economically disadvantaged and who may accept a lower settlement than what they would receive in court. They may settle for less because they do not have the resources, whether financial or emotional, to fight. ${ }^{176}$ There are concerns about the perpetuation of systemic inequalities. Focusing on interests, and looking at rights in the larger context of the party's goals instead of in insolation, can minimalize the legal rights belonging to individual groups who are already struggling to assert them. ${ }^{177}$

This paper does not propose to replace the ethical duty a lawyer has to competently pursue her client's interests within the bounds of legality; to represent her client by balancing competing interests ${ }^{178}$ and to advocate with balanced zeal. ${ }^{179}$ Instead it proposes to add to those existing duties. It seeks to recognize that in a non-adversarial dispute resolution process, a lawyer must be an advocate, but she must advocate with her counterpart counsel, not against her, in pursuit of the best deal for her client. She must ultimately recognize the self-determination of the client, and advocate in a way that allows the client to make an informed decision as to the outcome of her case.

Some argue that codification has little ability to impact behaviour and it may limit or inhibit individual reflection and reasoning by limiting assessment to whether a formal rule has been broken. ${ }^{180}$ However, it may actually be harmful to have one codified model of advocacy and behavioural norms that are revealed through a community of practice. ${ }^{181}$ First, it sends the signal that the only legitimate form of advocacy is the type found in an adversarial process, effectively delegitimizing non-adversarial lawyering. Second, if lawyers are left to learn acceptable practice norms through working in a community of practice it creates an unnecessary learning curve. By creating an ethical foundation for all lawyers to begin with, then nuance can be developed at the community level but basic principles can guide behaviour. Third, disciplinary

171 Macfarlane, "New Lawyer," supra note 9 at 106.

172 Menkel-Meadow, "Non-Adversarial," supra note 9 at 158; Menkel-Meadow, "Evolving Complexity," supra note 9 at 398-399.

173 Cromwell Report, supra note 1 at 30-31.

174 AAML, "Bounds of Advocacy," supra note 33.

175 Menkel-Meadow, "Many C's," supra note 145.

176 Hanycz et al, supra note 99 at 278.

177 Ibid at 299.

178 Woolley et al, Lawyers' Ethics, supra note 5 at 393.

179 Model Code, supra note 13 at R 5.1 (Advocacy).

180 Margaret Ann Wilkinson, Christina Walker \& Peter Mercer, "Do Codes of Ethics Actually Shape Legal Practice?" (2000) 45 McGill LJ 645 at 650; Macfarlane, "New Lawyer," supra note 9 at 45; Hanycz et al, supra note 99 at 127.

181 Mather, supra note 7. 
action cannot be sought for breach of community norms. There are fundamental duties and restrictions imposed on lawyers that we must uphold in our responsibility to the public as a self-regulated profession. ${ }^{182}$ Defining non-adversarial advocacy extends those duties to recognize behaviour that is perceived as being beneficial to family law clients, and is already being practiced and reflected in legislation. ${ }^{183}$

One option for a revision to the Model Code is set out below. The proposal reflects the idea that nonadversarial advocacy reflecting core values ${ }^{184}$ may improve lawyer behaviour and better reflect practice norms, legislation and reform initiatives. The revised rule recognizes some of the unique elements of family law, ${ }^{185}$ and aims to encompass the following values and ideas:

- Client-centered approach ${ }^{186}$ - The Model Code requires that lawyers ascertain their client's objectives. ${ }^{187}$ The lawyer's role is to "facilitate the client's accomplishment of her ends within the legal system" and to "interpret and work through the law to achieve the client's goals." 188 The revision recognizes that in a non-adversarial process, competent lawyers also recognize the client's goals and concerns beyond those provided by the law. A client-centered approach also emphasizes that the client is responsible for the final outcome, as opposed to a neutral third-party decision-maker. ${ }^{189}$

- Flexible advocacy - Advocacy may shift over the course of a file, as the client's needs change. A lawyer's role in a non-adversarial proceeding is different than in an adversarial proceeding. In an adversarial proceeding, it requires the lawyer to "raise fearlessly every issue, advance every argument and ask every question" 190 and ultimately allow a judge or arbitrator to make a decision. In a non-adversarial proceeding, the client is the final decision-maker, and as a result, what she needs from her lawyer may shift and change depending on the nature of the file and responses from the other party. ${ }^{191}$ For example, over the course of one negotiation, the client may need the lawyer to be a partisan advocate in the beginning, and as the client progresses through the cycle of grief she may need more facilitative advocacy from her lawyer towards the end of the file, or vice versa. ${ }^{192}$

182 Woolley et al, Lawyers' Ethics, supra note 5 at 81-85.

183 BC Family Law Act, supra note 27; Bill C-78, supra note 24.

184 Roadmap, supra note 22 at 17 (core values, aims and principles that should guide all family justice reforms include: conflict minimization; collaboration; client-focus; empowered families; integration of multidisciplinary services; affordability; voice, fairness, safety; and proportionality).

I also suggest a rule requiring lawyers to screen continuously for family violence, but that is beyond the scope of this paper.

186 Cromwell Report, supra note 1 at 20; Kruse, supra note 105; Macfarlane, "New Lawyer, supra note 9 at 106.

187 Model Code, supra note 13 at R 3.1-1(b) (Competence - investigating).

188 Woolley, Understanding, supra note 141 at 56.

189 IACP, Standards, supra note 152 at 3.2 (Advocacy).

190 Model Code, supra note 13 at R 5.1-1[1] (Advocacy).

191 Smith \& Graham, supra note 170.

192 Ibid at 2-3. 
- Proportionality ${ }^{193}$ - Advocacy that is proportionate to the issues and complexity of the case. ${ }^{194}$

- Problem-solving - A problem-solving approach allows for complex solutions that are only capable of design outside of the limited rights-based options available in court, ideally by empowering the client; ${ }^{195}$ solutions that meet the needs of both parties, and will endure. ${ }^{196}$

- Minimizing conflict ${ }^{197}$ - Advocacy that refrains from attacking the other side, but can be used to argue a strong case. The BC Guidelines, ${ }^{198}$ the IACP Standards, ${ }^{199}$ and the Toronto Study ${ }^{200}$ all suggest that family lawyers ought to minimize conflict. However, lawyers cannot be tasked with being the decision-maker as to what instructions may be antagonistic, and what instructions may not be. The client is tasked with providing instructions which the lawyer must follow; it is the nature of the solicitor-client relationship. ${ }^{201}$ That said, the lawyer can remind the client of his objective and that more often than not, antagonizing the other side is counterproductive to a deal that meets the interests of both sides. ${ }^{202}$ The lawyer can objectively reality check.

- Children - The nature of the solicitor-client relationship does not require consideration of interests beyond those that belong to the client. ${ }^{203}$ The Model Code provides that lawyers "should advise the client to take into account the best interests of the child, if this can be done without prejudicing the legitimate interests of the client."204 Therefore, a lawyer does not have an ethical obligation to consider the interests of a child who is impacted by the dispute. Whether lawyers have a moral obligation to consider children's interests is beyond the scope of this paper. That said, the BC Guidelines suggest that lawyers advise their clients to "put the children's interests before their own"205 (emphasis added). The BC Family Law Act requires dispute resolution professionals to advise their client that orders and agreements regarding guardianship, parenting arrangements, and contact with a child, "must be made in the best interests

193 Hryniak, supra note 20.

194 Cromwell Report, supra note 1 at 20.

195 Ibid.

196 Menkel-Meadow, "Non-Adversarial," supra note 9 at 158.

197 Dean G Pruitt \& Sung Hee Kim, Social Conflict: Escalation, Stalemate, and Settlement (New York: McGraw-Hill, 2004) at 20-27, and 89-91.

198 LSBC, "Guidelines," supra note 13 at Guidelines \#1 and \#5.

199 IACP, Standards, supra note 152 at 3.2(E).

200 Sowter, "Professionalism," supra note 6 at 187.

201 Model Code, supra note 13 at R 3.2-1[3] and R 3.2-1[5](f) (Instructions), R 3.2-1[5](k) (Informed of settlement), R 5.11[7] (Advocacy - A lawyer must never waive a client's legal rights without the client's informed consent); LSA, Code, supra note 108 at R 3.2-4 (Client Instructions); Woolley, "Fiduciary," supra note 3.

202 Bernard Mayer, The Dynamics of Conflict: A Guide to Engagement and Intervention, 2nd ed (San Francisco: JosseyBass, 2012) at 124-37; Macfarlane, "New Lawyer," supra note 9 at 105.

203 Tanovich, supra note 4.

204 Model Code, supra note 13 at R 5.1-1[4] (Best interests of the child).

205 LSBC, "Guidelines," supra note 13 at Guideline \#8. 
of the child only." ${ }^{206}$ And, Nicholas Bala has suggested that a lawyer has an ethical obligation towards his client's children. ${ }^{207}$ What a lawyer can do, ethically, is advise the client to consider her child's interests; but ultimately, if the client wishes to make a morally foolish decision with respect to that child, it is hers alone to make, ${ }^{208}$ assuming that it doesn't trigger an exception to privilege or confidentiality. ${ }^{209}$ In the context of a revised rule, the lawyer may remind the client of the impact of the dispute on her child through reality checking.

The Model Code could be revised as follows:

\subsection{The Lawyer as Advocate}

5.1-1 When acting as an advocate, a lawyer must represent the client resolutely and honourably within the limits of the law, while treating the tribunal with candour, fairness, courtesy and respect.

\section{Commentary}

[1] Role in Adversarial Proceedings - In adversarial proceedings, the lawyer has a duty to the client to raise fearlessly every issue, advance every argument and ask every question, however distasteful, that the lawyer thinks will help the client's case and to endeavour to obtain for the client the benefit of every remedy and defence authorized by law. The lawyer must discharge this duty by fair and honourable means, without illegality and in a manner that is consistent with the lawyer's duty to treat the tribunal with candour, fairness, courtesy and respect and in a way that promotes the parties' right to a fair hearing in which justice can be done. Maintaining dignity, decorum and courtesy in the courtroom is not an empty formality because, unless order is maintained, rights cannot be protected.

[2] This rule applies to the lawyer as advocate, and therefore extends not only to court proceedings but also to appearances and proceedings before boards, administrative tribunals, and arbitrators. mediators and others who resolve disputes, regardless of their function or the informality of their procedures. ${ }^{210}$

206 BC Family Law Act, supra note 27 at s 8(3).

207 Bala, Hebert \& Birnbaum, supra note 33.

208 Woolley, Understanding, supra note 141 at 92.

209 See for e.g. Model Code, supra note 13 at R 3.3-3 (Future Harm / Public Safety Exception); Smith v Jones, [1999] 1 SCR 455, 169 DLR (4 $\left.{ }^{\text {th }}\right) 385$ (SCC); Child, Youth and Family Enhancement Act, RSA 2000 c C-12 at s 3.1(3)(d); Child and Family Services Act, RSO 1990 c C-11 at s 72; Child, Family and Community Service Act, RSBC 1996 c C-46 at s 14. 
[2.1] Role in Non-Adversarial Proceedings - In non-adversarial interest-based proceedings such as family law negotiation, mediation, and collaborative practice processes, the lawyer has a duty to their client to adjust their advocacy depending on client needs. In order to do this, the lawyer has to exercise their duty to their client by considering not only their legal rights and obligations, but also their interests. The lawyer must consider more than the legal model, which means establishing and considering the client's financial stability, emotional well-being, the interests of the other spouse, and the well-being of their child(ren), if any, in order to determine how best to find a consensual resolution to the conflict, if possible. The lawyer must objectively reality check with their client to ensure the client has considered all of their options and the consequences of those options before making any decisions. The lawyer must remain objective. The lawyer is encouraged to problem-solve with their client, and to consider their client's needs in order to help them determine the best and most cost-effective way to achieve their desired result. The lawyer is also encouraged to problem-solve with opposing counsel to pursue a just outcome for the client.

\subsection{Definitions}

"reality check" means to measure whether the client's instructions are reasonable by continuously evaluating whether they reflect their interests, their financial stability, emotional well-being, and the impact of the conflict on their child(ren), if any; and, to discuss the interests of the other party with the client for the purpose of achieving a consensual resolution.

The Toronto Study suggests that codification of value-based behaviours may have a positive impact on the family law bar. While there is debate about the effectiveness of aspirational terms in the Model Code, ${ }^{211}$ the participants often looked to the Rules to justify their decision when they were debating an ethical dilemma. Practice-specific guidelines, such as the IACP Standards ${ }^{212}$ and the BC Family Law Guidelines, ${ }^{213}$ emphasize non-adversarial advocacy. Reform initiatives emphasize out-of-court dispute resolution processes. ${ }^{214}$ A revised rule for non-adversarial advocacy would bring the Model Code into sync with those initiatives, bring lawyers' ethics up to date, and may help to redefine (or define?) the role of the family law lawyer.

211 Alice Woolley, "What Should a Code of Conduct Do (or not do)?” (25 February 2016), online (blog): Slaw $<$ http://www.slaw.ca/2016/02/25/what-should-a-code-of-conduct-do-or-not-do/>; see also Mather supra note 7 at 47 (codes are important to family lawyers because they give them a sense of collective professional responsibility).

212 IACP, Standards, supra note 152; see also AAML, "Bounds of Advocacy," supra note 33.

213 LSBC, "Guidelines," supra note 13.

214 BC Family Law Act, supra note 27 at Division 1; Bill C-78, supra note 24; Cromwell Report, supra note 1. 


\section{CONCLUSION}

The negative impact on family law clients from poor lawyering is reflected in the conclusion by many participants that family law requires a "higher" ethical standard, ${ }^{215}$ presumably meaning, family law lawyers need to behave themselves. Are these lawyers collectively saying the law needs to change? By not updating the Model Code to incorporate non-adversarial advocacy, there is a gap. The Model Code is responsive to solicitor work, adversarial barrister work such as criminal law and traditional civil litigation, but it is not responsive to the uniqueness of non-adversarial family law and in particular non-adversarial lawyering in an ADR process. Revising the Model Code cannot hurt any more than the system we have now. Given the stakes involved for families, and for the justice system, providing guidance to family lawyers to encourage them to enter into an ADR process and be a non-adversarial advocate for their client, if that is their client's wish, has no downside.

215 Sowter, "Professionalism," supra note 6 at 183. 


\section{Appendix "A"}

Focus group Questions

NEGOTIATORS

1. What is "unethical behaviour" in family law negotiations?

2. As in love and war, is all fair in negotiating?

3. What do you do if you know your client wants to:

a. Leverage their spouse's emotional response.

b. Bluff or exaggerate (is there a difference between bluffing, exaggerating and outright lying?)

c. Misrepresent material information.

4. What type pressure is acceptable for a lawyer to place on his or her client to settle?

\section{MEDIATORS}

1. What is "unethical behaviour" in mediation? (by the mediator)

2. Are mediators responsible for fair outcomes? How do you know how far you can / should push to achieve a fair outcome?

3. How do you determine what information to share with the other side?

4. What do you do when you know one side is misrepresenting facts or law to the other side or to you? (unethical client behaviour)

5. What role do you play in designing, transmitting, and formalizing offers, and solutions?

6. Does the pressure to reach a settlement inform your decision making?

\section{COLLABORATIVE LAWYERS}

1. How do you define "uncollaborative" behaviour? What is "unethical behaviour" on a collaborative file?

2. What does it mean to be an advocate for your client in the collaborative process? Does "zealous advocacy" have a place in Collaborative Family Law?

3. What do you do if:

a. you know that your client is withholding or misrepresenting information that is material to the collaborative process? How do you define "material"?

b. If the client's real motivations for making a decision differ from what they "put into the room".

c. If the client wants to bluff or exaggerate his or her position in an effort to "get a better deal".

4. Have you ever felt that you or another collaborative professional pressured a client to stay in the process when perhaps it was not in their best interest? How do you ensure that the client is making his or her own decision?

5. Have you ever faced a situation where your personal relationship(s) with the other collaborative professionals have had a detrimental impact on the process? (I.e. power imbalance, close friendships/relationships among team members, business relationships among team members.) 